\title{
From Colonialism to Postcolonial Colonialism: Changing Modes of Domination in the Northern Areas of Pakistan
}

\author{
MARTIN SÖKEFELD
}

\author{
Introduction
}

\begin{abstract}
When was "the postcolonial"? This apparently simple question contains a number of difficulties relating to concepts, epistemology, and temporality (Hall 1996). These problems emerge from the fact that systems of colonization inscribe their marks so deeply upon the societies of both the colonized and the colonizers that they cannot simply be eradicated by the political act of declaring independence. Even after independence, such societies remain heavily under the influence of the "gravity," to use Edward Said's term, of colonial history $(1994,367)$. Arguably, decolonization begins before independence with freedom struggles against colonial hegemony and domination. And, it certainly continues after colonization has formally ended, as much time is needed to free social institutions and discourses from often subtle kinds of determination by the colonizing power-if that can ever be achieved. There is no simple dichotomy of the colonial and the postcolonial. Problems of periodization proliferate if "postcolonial" is taken to label a global process of transition. Yet when we take dates of independence not as "definite" but as "decisive" points of transition
\end{abstract}

Martin Sökefeld (martin.soekefeld@anthro.unibe.ch) is Assistant Professor at the Institute of Social Anthropology at the University of Bern.

I am grateful to the Deutsche Forschungsgemeinschaft for generously funding research in Gilgit and in the British Library's Oriental and India Office Collection. I thank the staff of the Oriental and India Office Collection for help in locating archival material. This article would not have been possible without the many people in Gilgit who readily shared their perspectives with me. While I did not need a formal research permit from the people of Gilgit to work in their town, I am very grateful that they enabled my research with their great hospitality and friendship. I would like to thank Katrin Gratz and Georg Stöber for their valuable comments on an earlier version of this article. I also have to acknowledge the very insightful comments and suggestions from Ann Waltner and two anonymous readers of the Journal of Asian Studies.

The Journal of Asian Studies 64, no. 4 (November 2005):939-973.

(C) 2005 by the Association for Asian Studies, Inc. 
(Frankenberg and Mani 1993), the difficulty can be reduced by narrowing the scope to specific colonized areas. It seems reasonable to argue that this decisive date for India and Pakistan was August 14 or 15, 1947.

The high mountain region today called the Northern Areas of Pakistan, which will be discussed in this article, is an example of the complexity of this problem. The British left the former Gilgit Agency (as this region was called in colonial times), a peripheral but nonetheless strategically important part of colonial India, on July 31, 1947, two weeks before independence. The area thus began a process of transition that, as is argued from recent nationalist perspectives, even today has not reached a stage of decolonization in a meaningful sense.

The deconstructive analysis of postcolonial studies has shown that colonialism did not operate through a simple dichotomy of colonizers versus colonized, but was subverted by ambivalence and continually had to be reconstructed (Prakash 1992, 169). Colonialism was not simply a matter of the West versus the non-West. This certainly holds true for the Northern Areas of Pakistan. Here the dichotomy became blurred by intertwining histories of domination: until 1947 the area was subjected to British rule and then simultaneous domination by Britain and Jammu and Kashmir.

Although independence is celebrated in India and Pakistan every year on August 15, the then Gilgit Agency was freed from British control two weeks earlier. On that day, the Gilgit Agency became part of neither India nor Pakistan, but rather was "given back" to the control of Kashmir. In Gilgit, that day was not so much an event of joyful celebration as it was of uncertain consideration as to what the future would bring. The people of Gilgit have their own freedom day (yom-e $\bar{a} z \bar{d} d \bar{\imath})$, which is commemorated on November 1, the date when the people of Gilgit started their own freedom struggle (jang $\bar{a} z \bar{a} d \vec{\imath}$ ) — not against the British, but against the rule of the maharaja of Kashmir. The struggle's aim was to merge the Gilgit Agency with the newly born Muslim state of Pakistan. Until today, however, the (now) Northern Areas have never been a legal part of that country. It is just "under the administration of the Government of Pakistan." Several times in the last few years, the celebration of yōm-e āzādī on November 1 has been boycotted by local oppositional groups that perceive the present Pakistani administration not as constituting a "rule of freedom," but as a new colonial system.

According to the perspective of these groups, Gilgit and the surrounding mountain country have been subjected to three different powers in the last 150 years: Kashmiri, ${ }^{1}$ British, and Pakistani. Instead of locating a uni- or multilinear transition from colonialism to the postcolonial, we discover only transitions between specific relations and modes of domination and subalternity in the history of the Northern Areas. We can find decisive differences in the relations between the dominating power and the subaltern local population: fierce opposition and at times incidents of insurrection against both Kashmiri and Pakistani rule but much less against the British. What is the reason for this difference? That question is the topic of this article. To prevent any misunderstanding, I emphasize from the beginning that I am not at all interested in the continuation or restoration of an image of benevolent and just rule that the British liked to present of themselves.

${ }^{1}$ Although technically speaking the area was not ruled by the Kashmiris, but by Dogras (and earlier by Sikhs) who ruled over Jammu and Kashmir State, I will for reasons of convenience employ the shorthand of "Kashmiri rule" throughout the article-as does most of the literature on the history of this region. 
My exploration started with anthropological fieldwork between 1991 and 1993 on ethnicity in Gilgit. ${ }^{2}$ During this time, I realized that I had to deal not only with diverse forms of local "ethnic" identities but also with the political conditions in the aftermath of British colonization and the Kashmir dispute that gave rise to a new, inclusive political identity. A nation of the Northern Areas was in the process of being imagined. As a result, my field research-later supplemented by archival research in London-became to a considerable extent focused on this political development. The "freedom struggle" - that is, the struggle against domination and an administration considered alien - was a central motif in the stories and histories that I was told in Gilgit. In this article, I want to discuss the different modes of domination in the history of what is today the Northern Areas of Pakistan. The article focuses on the western part of the Northern Areas, comprising the erstwhile Gilgit Agency, and especially on the town of Gilgit. ${ }^{3}$

After starting with a discussion of Michel Foucault's and Ranajit Guha's conceptions of power and domination that enable the distinction between different modes of domination according to the degree to which they rely on violence or consensus, I will explore the different discourses of legitimation of Kashmiri and British rule in Gilgit as they emerged from British sources. I dwell especially on British strategies to develop a "practical" hegemony and analyze the role of the Gilgit Scouts for this purpose. In a section on protest and resistance in the Gilgit Agency, I show that this hegemony remained, however, only partial and never extended to all sections of the population. The British self-perception of their domination becomes especially visible on the eve of their leaving the agency in 1947. During the term of a Kashmiri governor, lasting from August 1, 1947, until the end of October, which I explore subsequently, Kashmiri rule was again unable to achieve a degree of acceptance and consensus in Gilgit. In the section on the Northern Areas under Pakistani administration, I point out that the initial legitimacy of Pakistani rule was increasingly lost and was then replaced in part by violent resistance, resulting finally in political movements in which autonomy and independence were demanded. Pakistani and British modes of domination are compared in the last part of this section. Finally, I discuss relations between power and knowledge in the Northern Areas and the possibility of writing nonessentialist histories under the polarizing conditions of power.

\section{Modes of Domination: Relations of Force and Relations of Power}

As in other parts of the colonized world, for both general and specific reasons, in Gilgit there was no simple dichotomous opposition of power between colonizers and the colonized, or, put more generally, between dominators and the dominated, between rulers and the ruled. The general reason emerges from the nature of power itself. Power is one of the most complex concepts in the social sciences, with definitions and understandings, at times quite contradictory, abounding. ${ }^{4}$ The debate on power Areas.

${ }^{2} \mathrm{My}$ fieldwork was divided into two terms. In total I stayed fifteen months in the Northern

${ }^{3}$ Baltistan and the adjacent valleys toward the east share the current political condition with Gilgit but have a very different historical trajectory. Therefore, these areas are not considered here.

${ }^{4}$ For a recent discussion from an anthropological perspective on power, see Westwood 2002. 
has been strongly influenced by Michel Foucault, who emphasizes the ubiquity of power: power is not only vested in political entities such as the state and its institutions or in collective subjects such as classes but also dispersed in political and social relations or networks $(1979 \mathrm{~b}, 55)$. He describes power as a "more-or-less coordinated (in the event, no doubt, ill-coordinated) cluster of relations. .." $(1980,199)$. A significant element in his thought is the idea that power depends on the agency of both the one who commands and the one who obeys or follows $(1982,219-22)$. The power of the ruler is not aimed at the negation of the agency of those ruled, but at the manipulation of their actions in order to achieve certain goals. Both the dominant and the subaltern possess power and are affected by it - if of course in highly unequal measure. Power is an element of all social relations (Touraine 1981, 33) - not only of those of domination - and there is no social action without power. In this article, however, the discussion is limited to relations of power in the context of government and administration.

The broad conceptualization of power employed here requires a clear distinction between power and force or violence. Force/violence does not recognize the agency of the individual subjected to force. According to Foucault's distinction, the target of force is not the action, but the body of the dominated. Force/violence establishes an almost causal relationship between dominators and the dominated. Under the pressure of violence, one has no choice but to comply. Ultimately violence risks destroying power: it threatens the physical elimination of subalterns. Once subalterns are removed, there is no one left to comply with the power, and the relationship on which power is based disappears. Consequently, the dominators no longer have power. Therefore, the relations between dominator and subaltern cannot be permanently based solely on violence. Relations of violence and force have to be turned into relations of power in order to maintain stable and enduring structures of domination. In accordance with Hannah Arendt (1970), I regard the distinction between violence and power as crucial for understanding different modes of domination. This is different from Ranajit Guha's concept of the "configuration of power" $(1997,20)$, in which power encompasses coercion/violence and which therefore cannot explain why the execution of violence in the end destroys power.

Guha's model is probably the most influential theorization of power and domination within the field of South Asian studies. It must be read within the frame of the efforts of the Subaltern Studies group to question radically both the elitist bias of Indian historiography and the Eurocentrism of a Western history of India that endeavors to present the colonization of the subcontinent as an almost necessary chain of events which raised India from a stage of the prepolitical to the level of the truly political.

Both approaches tend to monopolize power and the ability to act politically in the hands of colonizers and/or the (Westernized) nationalist elite (Guha 1982; see also Chakrabarty 2000). To show that neither the British colonialists nor the Indian bourgeoisie achieved a degree of hegemony that allowed for a claim of acting on behalf and with the consent of "the Indian people," Guha rightly emphasizes the coercive nature of the colonial regime. He theorizes power as the relation of domination and subordination in which domination is characterized by coercion and persuasion and subordination is characterized by collaboration and resistance-both to varying degrees. The colonial regime is then defined by a power structure in which persuasion never outweighs resistance and in which hegemony — defined in these terms-accordingly is never achieved (Guha 1997, 20-23). The autonomy of subaltern agency, expressed in acts of resistance, is thus emphasized. 
My issue with Guha's model is slight. I do not intend to question the overall nonhegemonic character of colonial rule in India, but I will argue that the modes of domination on which colonialism relied changed according to the extent to which these modes resorted to power or violence. Furthermore, I am of the opinion that questions of consensus, legitimacy, or hegemony cannot be answered on a very general level. The colonial regime acted quite differentially toward the various sectors of the population and was in turn evaluated very differently by these sectors. In his interpretation of colonial relations, Guha relies most importantly on the distinction between the Indian bourgeoisie and the subalterns or "the people." I regard this distinction as too gross for the area discussed in this article. Apart from the fact that it is quite futile to attempt to discover a bourgeoisie in the erstwhile Gilgit Agency, the subalterns were composed of many different elements not affected by the colonial regime in a uniform manner.

Theoretically force/violence and power can be distinguished quite clearly, but in practice making that distinction is much more difficult. Relations of power are founded upon possible structures of violence. ${ }^{5}$ At its limits, power is either given up to or turns to violence. Power always coexists with at least the option for violence. Colonial relations, then, cannot be built only upon power; colonial power has to be backed by force. At the other limit of power is consensus or "persuasion," in Guha's term (1997). When consensus is achieved completely, power becomes unnecessary. Consensus, expressed in the legitimacy of a given power, reduces the friction of power relations. When a high degree of legitimacy is obtained, power achieves its aims smoothly. Toward the other end of the spectrum, when consensus is replaced by the threat or actual application of violence, friction increases and turns into resistance. The powers of dominant and subaltern become antagonistic. With the threat of violence, the dominant power can try to reduce the power of the subalterns-but it may produce even more resistance. To avoid that friction, systems of domination must aim at establishing their own legitimacy, at building hegemony. Legitimacy may be achieved to a certain extent at one point in time and may utterly fail at another. Accordingly, modes of domination can be distinguished according to the degree to which they rely on legitimacy or violence. Modes of domination are contingent upon changes in historical context and conditions.

The second reason for the nondichotomy of colonial relations is that the field of domination comprising both colonizers and the colonized was inhabited by a number of intermediate relationships of domination. Relations of power are not only found between colonizers and the colonized but also in all other social relations anchored in or effective on a given locality. Relations between local elites or ruling families and their subjects, between different kinds of social groups, or within families, gender relations, and so on, are all marked by certain relations of power and/or violence that affect each other and are not independent of colonial relations. Like power, subalternity is a matter of degree. The subalternity of an actor in one instance does not preclude his (or, in the present context less frequently, her) domination in another.

Against this outline of a theory of power and violence, I want to analyze colonial relations in the Gilgit Agency. I understand colonial relations in a rather broad sense that accommodates not only British domination but also all kinds of domination perceived locally — that is, by those colonized—as "foreign." By employing the term

${ }^{5}$ Arendt's distinction between power and violence is even more radical than that of Foucault. For her, power is solely founded upon consensus, but power that totally abstains from violence is more a liberal ideal or fiction than a political experience $(1986,71)$. 
Table. Changes of government in Gilgit

\begin{tabular}{|c|c|}
\hline ca. 1842 & First occupation of Gilgit by troops from Kashmir \\
\hline 1846 & Conquest of Gilgit by Raja Goharaman from Yasin \\
\hline 1860 & $\begin{array}{l}\text { Death of Goharaman, reestablishment of Kashmiri domination in } \\
\text { Gilgit }\end{array}$ \\
\hline 1879-81 & $\begin{array}{l}\text { Establishment of the first British Agency in Gilgit by Colonel } \\
\text { Biddulph, parallel with Kashmiri administration }\end{array}$ \\
\hline 1889 & $\begin{array}{l}\text { Reestablishment of the British Gilgit Agency, period of "dual } \\
\text { control" by the Kashmiri and British }\end{array}$ \\
\hline 1935 & Lease of the Gilgit Agency by the British, end of dual control \\
\hline July 30, 1947 & $\begin{array}{l}\text { Transfer of the administration of Gilgit from the British to } \\
\text { Governor Ghansara Singh from Kashmir }\end{array}$ \\
\hline November 1, 1947 & $\begin{array}{l}\text { Insurgence against Kashmir, establishment of "Islamic Republic of } \\
\text { Gilgit" }\end{array}$ \\
\hline November $16,1947-$ & Establishment of Pakistani administration \\
\hline
\end{tabular}

"colonial" equally for Western and non-Western powers, I avoid the recentering of "postcolonial discourse" on a dominant Western perspective that is inevitable if "colonial" remains reserved for European powers (see McClintock 1992, 86). The colonial character of a given relation of domination becomes, then, a matter of both a structure of institutions and practices as well as signification. The same relations and practices may be accorded different signification in different times or by different persons from different perspectives and positions at the same time, depending on the degree to which consensus and the legitimacy of those dominating are achieved. I will argue in particular that the Pakistani domination of the Northern Areas had considerable legitimacy in and after 1947 but that later certain actors signified it as a colonial regime.

\section{Discourses of Legitimacy on the "Northern Frontier"}

That there were two colonial powers in the area, Kashmiri and British, governing with different though not always clearly delimited competences and competing in many respects determined to a large extent colonial relations in Gilgit until 1947 (see table). This rivalry was a competition not only for actual political control over the area and its people but also for the legitimacy of that control. Legitimacy is required to turn domination by force into domination by power. In this section, I will focus on the analysis of this discourse of legitimacy. My sources for these discourses are very limited, as they consist of the writings of British officers only. Still, in these texts, we can clearly discern the development of a separation between British and Kashmiri legitimacy. This legitimacy concerned mostly the self-legitimation of rule and much less the acceptance of that legitimacy by those ruled-hegemony is thus out of question. We find, however, that by distancing their rule from Kashmiri rule-that is, by achieving a legitimacy that consisted also of questioning the legitimacy of Kashmiri rule - the British were able to achieve a degree of consensus from a part of those whom they dominated. The British documents do not allow for access to the "hidden transcripts" (Scott 1990) of the colonial subjects who did not share in this consensus. Between the lines, and sometimes quite explicitly, however, expressions of discontent and movements of resistance can also be read. 


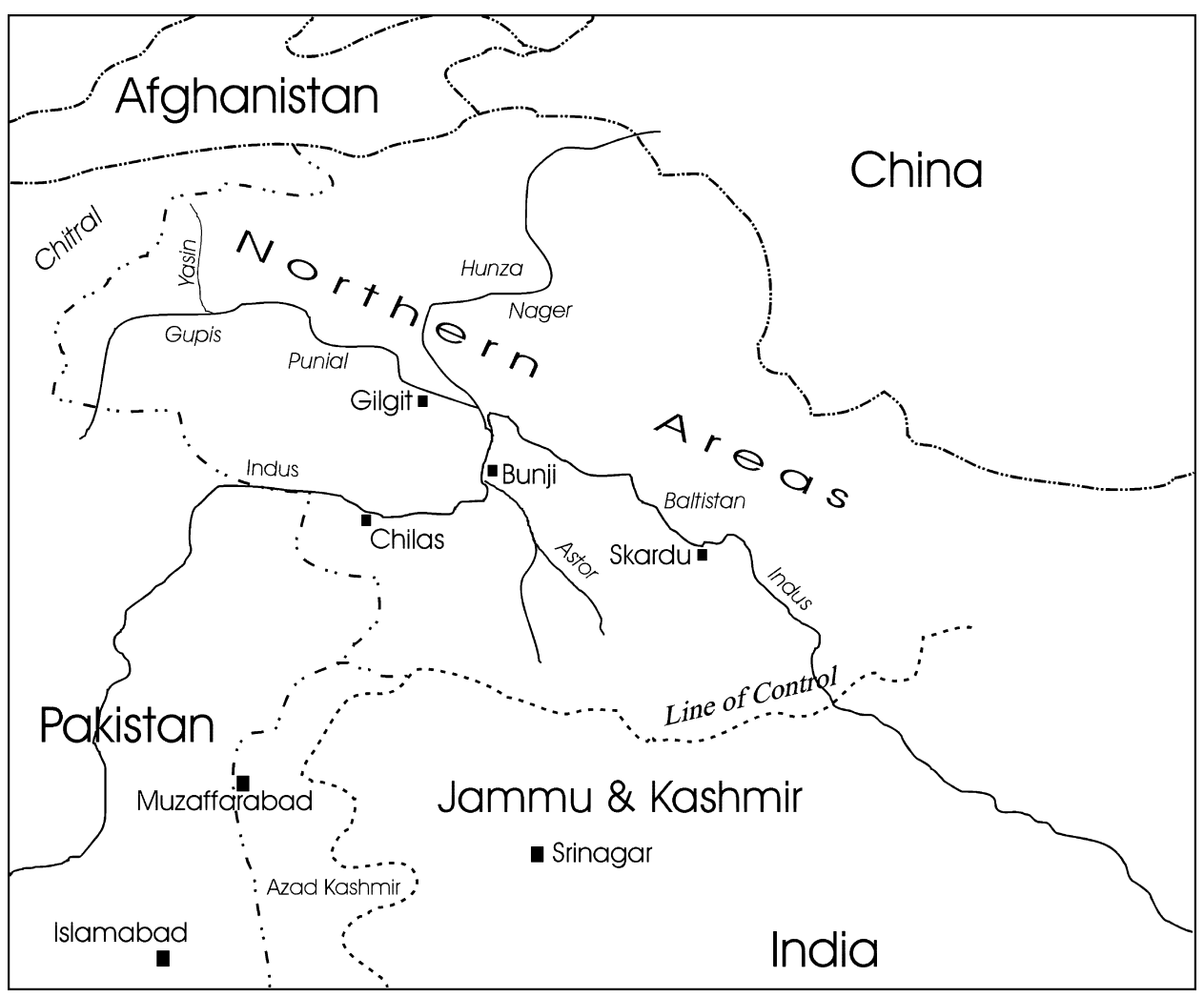

Map. The Northern Areas of Pakistan.

Troops from Kashmir established their control in Gilgit for the first time around 1842. At that time, Kashmir was a province of the empire of the Sikh Maharaja Ranjit Singh. For two or three decades prior, Gilgit had been under the control of rulers who too were not "at home" in Gilgit but had invaded the place from neighboring valleys such as Yasin (Suleman Shah and Gohar Aman), Punial (Azad Khan), and Nager (Tahir Shah). The domination established by these rulers could be regarded as "colonial": some sources describe local resistance at least against the rajas of Punial and Yasin, who were accordingly regarded as foreign usurpers of rajaship in Gilgit (see, for example, Shah Rais Khan 1987). Legitimacy of rule was at that time mostly conceived in terms of dynastic legitimacy; that is, it was more a matter of relations among the dominant than of relations between rulers and the ruled (see, for example, Shah Rais Khan 1987, 346; Biddulph 1880/1971, 138).

After defeating Maharaja Ranjit Singh in the Punjab, the British made over Kashmir by the famous Treaty of Amritsar (1846) to the Dogra Raja Gulab Singh of Jammu, who thus became maharaja of Jammu and Kashmir. Gulab Singh's actual takeover of Kashmir had to be aided militarily by the British due to much resistance to the new ruler. By assuming power in Kashmir, Gulab Singh also became successor of the Sikhs in Gilgit, even though Gilgit was formally excluded in the Treaty of Amritsar, which ceded only the territories east of the Indus to Gulab Singh. Gilgit is situated northwest of the river (see map). Nevertheless, Frederic Drew, an Englishman who served Gulab Singh's son Ranbir Singh in a range of important positions, tried to legitimate the claim of the Dogras to control Gilgit. According to him, the 
geographical specification of the Treaty of Amritsar was simply due to a lack of appropriate knowledge, not to the explicit intention to exclude Gilgit from the territory sold to Gulab Singh (1875/1980, 439-40). Drew simultaneously tried to rule out other contestants of possession of Gilgit, namely, the regional rajas. His first strategy referred to the suffering of the population caused by the cruelty of Gilgit's conqueror, Gohar Aman, whom he described as "a most bloodthirsty man" of extraordinary brutality. "He seems to have had a special enmity and spite against the people of Gilgit, who suffered terribly under his two reigns. .." (437). Second, Drew denied the dynastic legitimacy of the regional rajas who claimed rulership of Gilgit: "We have seen that Karim Khan was not of the old rulers of Gilgit; his father had conquered it; his brother and he himself had been turned out by Gaur Rahman [Gohar Aman], who had just the same right to it as the other's father - that is, no right at all, but only the power of acquiring it" (438-39).

Also, the very first British visitor to Gilgit, P. A. Vans Agnew, questioned the legitimacy of the pre-Kashmiri rulers. He traveled the area in 1847 to negotiate with the rulers of Nager, Hunza, and Yasin. After reporting that a large part of the population of Gilgit had been sold into slavery by the Rajas Suleman Shah, Azad Khan, and Tahir Shah, he continued in his diary: "It is not to be wondered at that a tribe of whom two-thirds had suffered the extreme of despotism should have lost loyalty to their rulers. Such was the case in the time of Secundur Khan. . . It was, however, so distasteful to [the population] as to induce a conspiracy in favor of their neighbor the Rajah of Yeseen by name Gour Aman" (1847, 288). Matters became worse still for the people of Gilgit. With a certain irony, Vans Agnew went on: "Gour Aman was recognized Rajah by the Gilgitees. He fully realized the fable and the inertness of the deposed Chief was soon contrasted with the rapacity of his elected successor: He sold into slavery every living soul in Gilgit upon whom he could lay hands" (288). ${ }^{6}$ The reports of both Vans Agnew and Drew in effect legitimized Kashmiri rule in Gilgit, even if that rule was not warranted by the Treaty of Amritsar, as Drew realized. We can infer that in the beginning of Kashmiri domination in Gilgit, the British and the Kashmiri discourse on the legitimacy of rule in Gilgit converged. But, the respective discourses of legitimacy became separated when, during the reign of Gulab Singh's son Ranbir Singh, the British started to question whether the maharaja was indeed a loyal and effective trustee of British interests in the northern frontier region (see Yasin 1984; Alder 1963). A result of this distrust was that the British started to pursue seriously their interest directly and with their own personnel. After a few explorers and surveyors had traveled the area, Colonel John Biddulph went to Gilgit in 1877 to become the first British agent there.

The maharaja was opposed to the posting of a British agent in Gilgit. From its inception, Biddulph's mission was regarded by the maharaja as a surveillance of Kashmiri activities - that is, a restriction of Kashmiri domination. Consequently, from the beginning, Biddulph was to suffer a hostile and very obstructive attitude of the Kashmiri authorities. Kashmiri personnel effectively boycotted him, and the governor even prohibited the people of Gilgit from working for Biddulph or trading with him ("Memorandum on the Present Condition of Affairs in Gilgit," OIOC, L/P\&S/18/ A18/2, 1881, p. 26). Biddulph in turn was very critical of the Kashmiri way of governing the area and wrote in his report: "The misgovernment and oppression suffered by the people of Gilgit during the last three years exceed what they had to endure from former Governors. After the result of this had become apparent in the

${ }^{6}$ On the history of the slave trade in the area, see Müller-Stellrecht 1981. 
recent disturbances, it would be thought that some relaxation of harshness would be found advisable. During the last two months things have gone from bad to worse, and the system of oppression has changed to one of wholesale plunder" ("Memorandum on the Present Condition of Affairs in Gilgit," OIOC, p. 27).

The "plunder" to which Biddulph refers was the forced extraction of agricultural produce mainly for the purpose of provisioning the Kashmiri garrison. The mountain path from Kashmir to Gilgit was long and haphazard. Moreover, it remained closed for half of the year. Supplies for the maharaja's troops could not be imported for the most part, so they had to be procured locally. The people themselves had to carry these extractions to Gilgit by way of beg $\bar{a} r$ (forced labor), a practice that was much resented (see Vans Agnew 1847, 285).

We have no independent sources about attitudes of the people of Gilgit toward Kashmiri rule, but the scarce remarks in the British reports such as Biddulph's reference to "recent disturbances" and Vans Agnew's remark about discontent indicate that the difficulties of the Kashmiri in preserving their grip over Gilgit were not only due to actions taken by rivaling rajas of the area who wanted the place for themselves. The reconquest of Gilgit by Gohar Aman in 1852 might not have succeeded without the collaboration of the local population-in spite of the earlier experience of his rule. ${ }^{7}$

In effect, Kashmiri domination in Gilgit was a matter of force. It was established violently by conquest; it met resistance to the point of expulsion; and it could guard itself only by way of a military force that was directed against possible local resistance, the maintenance of which could only be secured by dispossessing the local population of a considerable part of its produce. This was no new experience for the people, since the local potentates before had ruled by similar means-except that some of them could claim a certain dynastic legitimacy for their despotism.

The British established their position in Gilgit by very different means. They never had to conquer the place. Through the Treaty of Amritsar, its dominant interpretation, and British interest in establishing the Kashmiri force as a frontier guard in Gilgit, the British provided (particularly in the last instance) the reason for the entrenchment of the maharaja's troops in Gilgit—after all, Jammu and Kashmir was a native state in British India. That fact was probably not widely known in Gilgit at that time, however, and the British thus appeared as contestants and challengers of Kashmiri domination there, at least after Biddulph's time. Biddulph himself was met with deep distrust from the rulers of the neighboring valleys, especially Hunza, Nager, and Yasin-probably because they associated him with the much-despised Kashmiri forces. Because Biddulph was unable to establish whatever the British regarded as "friendly relations" with these rulers and because of a reorientation of British frontier politics, the Gilgit Agency closed down after four years in 1881.

When the agency reopened in $1889,{ }^{8}$ Algernon Durand, the political agent at the time, was at pains to dissociate himself from the Kashmiri officials and tried to establish direct relations with the important persons of the agency, independent of Kashmir (1899/1977, 137). He executed a multilayered strategy of domination in Gilgit. On the one hand, he was to back his position by military force. In addition to two hundred Gurkha soldiers, Kashmiri Imperial Service Troops were stationed in

${ }^{7}$ The Kashmiri were only able to reconquer Gilgit in 1860 after Gohar Aman had died.

${ }^{8}$ Among other things, the efforts of the amir of Afghanistan toward Chitral, situated to the west of Gilgit, and the continuing instability of Gilgit and the surrounding valleys provided the rationale for the renewed British presence in the area (Stellrecht 1998, 67; Yasin 1984, 89-90). 
Gilgit. That is, for the first time, a military body came to the place commanded by British officers, who extended their own vision of discipline and training to the troops. ${ }^{9}$ But on the other hand, Durand employed many means to enable trust and respect on the part of those locals whom he regarded as the "natural leaders of the country" (137).

To the horror of the Kashmiri governor, Durand sent home the hostages who were kept by the Kashmiri authorities in Gilgit in order to prevent any hostile activities in Hunza and Nager $(1899 / 1977,136)$. Whenever he was offered gold-for example, in support of the submission of some petition-Durand accepted the offer symbolically by touching it and then returning it to the donor, in sharp contrast to Kashmiri officials, who always had kept what was offered to them $(1899 / 1977,220$ 21). Central to Durand's strategy of domination was the annual jalsa that he established in the first year of his term. It was a week-long celebration of British rule in Gilgit culminating in the darbarr, the reception of rajas and notables. Although being present at this darbār meant acknowledging the British power in the area, the occasion also implied that respect was paid to the attending rajas of the area by honoring the rules of precedence in staging the event. A British observer emphasized the "unique atmosphere of homage and good will to the British Government" that characterized the darbār and asserted that it was "a solemn and impressive ceremony in the eyes of the locals" ("Memorandum on the Future of the Gilgit Agency/Enclosure to Demiofficial Letter from Lt. Col. G. D. Oglivie, Resident in Kashmir," no. 355-C/30, December 18, 1930, OIOC, R/2[1083/286], pp. 19-20). A later political agent, Major A. D. Macpherson, pointed to the disciplining function of this political ritual, which gave the British officers a most effective opportunity for publicly rewarding or reprimanding (Gilgit Diary, March 1914, OIOC, L/P\&S/10/826).

At the same time, the darbār placed the British agent firmly above Kashmiri authorities, as the Kashmiri governor, the wazīr-e wazārat, was (like all the rulers of the region) required to offer nazar to the political agent. This practice was resented and criticized with such regularity by the wazìr-e wazārat that it was noted in the Gilgit Diary (the official record of affairs) when in 1935 the wazīr-e wazārat raised no objection against it for the first time (March 1935, OIOC, L/P\&S/12/3285). Usually the darbār was followed by sportive festivities in which many people participated. During the first of these events, Durand was able to score further respect when he, together with his assistant and players from Gilgit, defeated the polo team from Nager, which, according to Durand, had until then remained undefeated (1899/1977, 228). The struggle for superiority here was fought to a large extent on the field of symbols. The British were of course not content with symbolic domination, and the symbolic assertion of their position was backed by the newly developed military force.

In 1891 Durand showed that he was determined to turn symbolic superiority into "real" domination whenever it was required for British interests. Safdar Ali, mīr of Hunza, was not ready to accept British domination but played with the option of opening Hunza for a Russian force. He was ordered, as a consequence, by the Government of India to ensure complete access to Hunza for the British (Alder 1963, 228-29). When Safdar Ali defied the order, the British military attacked a combination of men from Hunza and Nager at the fort of Nilt in Nager. Although the position of Hunza and Nager seemed quite invulnerable due to topographical con-

${ }^{9}$ British reporter E. F. Knight, who traveled the area widely when the political agency was reopened, emphasized the difference between these troops and the large but "undisciplined" and "useless" Kashmiri force that had garrisoned Gilgit before (1893/1991, 285-86). 
ditions, the forces commanded by the British officers succeeded in capturing the fort. After that victory, both Safdar Ali and Azur (Uzr) Khan, son of Mīr Jafar Khan of Nager, fled and resistance in Hunza and Nager collapsed. Nazim Khan replaced Safdar Ali as mīr, and in Nager power was reverted to the old mīr. Except for the "siege of Chitral" in 1895, this "Hunza-Nager campaign" was the only time when the British used violence against one of the little states on the "Northern frontier."

Durand's strategy exhibited an almost Foucauldian insight into the rules of the power game. He and his successors used force and violence only when their domination and power were challenged. But for the most part, they relied on techniques of "impression management" (Goffman 1959): they strove to appear less as antagonists and usurpers of power than as protectors and benevolent rulers. This strategy was summarized by a later British observer as follows:

[Durand's] edifice rests upon three main props: (1) a firm belief in the invincible strength of the British Empire, (2) an unquestionable assurance that the British officer, and especially the Political Agent, is a creature of superior clay, who will give protection against the Kashmir ogre, and whose voice must be hearkened to and obeyed, as if it were the voice of a god, (3) a policy towards the people of the Political Districts and their rulers based on liberality, justice and courtesy, with a minimum of interference, by which their contentment should be secured.

("Resident in Kashmir, December 14, 1927, Appendix to the 'Administration Report of the Gilgit Agency," 1927, OIOC, L/P\&S/12/3288, p. 5)

This "wise policy" of the British, as journalist E. F. Knight called it (1893/1991, 285), was very effective in "pacifying" the region. This "pacification" was very different from the strategy of domination that Kashmir had tried before and which never had allowed the maharaja to enjoy a rulership of the area that did not constantly face resistance and which was always in danger of eviction. The Kashmiris in Gilgit were never in a position in which they could renounce violence-violence that nonetheless was hardly effective. The British "pacification" of the Gilgit Agency bore all characteristics of Edward Said's description of that mode of domination — all of which Kashmiri rule had lacked: "In a word, the Empire must be wise; it must temper its cupidity with selflessness, and its impatience with discipline" (1995, 36-37).

The self-perceived benevolence and civilizing mission of British rule in the Gilgit Agency is most clearly expressed in Political Agent Macpherson's speech addressing the rulers and notables of the agency at the darbār of 1911. This speech is a striking case of self-celebratory colonial discourse and is a clear example of what Ranajit Guha calls the "idiom of improvement," by which the British attempted to achieve hegemony (1997, 30-33). British colonization of the Gilgit Agency is presented simply as a story of progress. Comparing past and present, Macpherson celebrated the "pacification" of the area and the improvements achieved by British rule:

You older men should never be tired of telling the younger generation what a difference there is in comparison with the past and telling them to whom they always should be grateful. No interference in your religion, each man can be man and say so, you cannot be bought and sold and sent to other countries. And all that you are asked to do is to live at peace and obey those set on authority over you. . . Roads have been made, bridges erected, cultivation increased, Postal and Telegraph facilities for all. Since I have known the Agency I have noted the great progress and difference amongst all in the manner of increased social amenities, better clothes, most of us 
now drink tea and sugar and salt are recognized necessities. The standard of living seems to have improved amongst all classes.

("Speech of Political Agent Maj. Macpherson in Gilgit at Darbar Held May 12, 1911," OIOC, IOR R/2[1081/260])

After the Gilgit Agency had been reestablished, Kashmiri authorities stayed in Gilgit and so remained the implicit rivalry between the British and Kashmiri, which at times became manifest. "Dual control" was instituted. Formally, competences were divided: Kashmir administered the Gilgit wazārat, which comprised the tabsil (subdistrict) of Gilgit (including Gilgit Town), Bunji, and Astor. All other parts of the area were controlled mostly indirectly by the British. Dual control, however, did not reduce competition for power, but rather fostered it. Time and again, the political agent complained that the wazīr-e wazārat was encroaching upon his realm of power (see, for example, "Report by the Resident in Kashmir on a Tour in the Gilgit Agency, August/September 1935," citing Political Agent Maj. Loch, 1927, OIOC, L/P\&S/12/ 3287, p. 5; "Memorandum on the Future of the Gilgit Agency," 1931, OIOC, L/ $\mathrm{P} \& \mathrm{~S} / 12 / 3287$, pp. 17-18), ${ }^{10}$ and most probably the opposite was equally true (although I lack documentary evidence for this). The dissensions culminated in the dispute about whether Hunza and Nager were parts of Jammu and Kashmir State. This conflict arose when, with the scheme of the formation of the "Federation of Indian States," the question had to be answered whether Hunza and Nager too could join the federation or were to be represented by Jammu and Kashmir (Sökefeld 1997b, 261-62). From 1938 onward, this dispute produced a great number of reports and diplomatic exchanges. For Gilgit Tahsil, the rivalry between Kashmir and Britain was solved to a large extent when the British leased this part of the Gilgit Wazārat from the maharaja in 1935.

In their reports, British officers boasted that in contrast to the Kashmiri officials, they had been able to establish a sympathetic relationship with the inhabitants of the area. The British resident in Kashmir wrote about the Kashmiri officials after inspecting the Gilgit Agency: "Officials of this class are necessarily wholly out of sympathy with the population with whom they have to deal. At best they are regarded with tolerant amusement. Very often they are hated and despised. .." ("Report of the Resident in Kashmir on a Tour in the Gilgit Agency, 1927," OIOC, L/P\&S/12/3288, n.p.). In a letter to the political secretary of the Government of India in the Foreign and Political Department, New Delhi, the resident in Kashmir relayed that "[t]he rulers and inhabitants of the Political Districts who are fair-skinned, followers of Islam and natives of Central Asia look to the Political Agent as their protector against aggression by the Maharaja, who represents to them the opposite of themselves in every way and the embodiment of all that India has always stood for in Central Asian eyes" (quoting the resident in Kashmir of 1927, October 10, 1933, OIOC, R/2[1078/ 241], n.p.). This statement of the resident can be read not only as establishing a contrast between the "inhabitants of the Political Districts" and the Kashmiri but also as affirming the opposition between the British and Kashmiri. The British and the people of the Gilgit Agency were situated on the same side of the opposition. The British and the people of Gilgit shared some characteristics but were not the same and equal. The British subjects in the agency were, in Homi Bhabha's words, "almost the same, but not quite" $(1994,86)$. This similarity was not a matter of mimicry of

${ }^{10}$ This Kashmiri-British competition was not only limited to the Gilgit Agency but also concerned the position of the maharaja in Srinagar. 
and education to British ways of life, as in the cases that Bhabha analyzes, but rather was a matter of nature, of (almost) common race: the "fair-skinned" inhabitants of the Gilgit Agency were, to quote Bhabha again, almost the same and almost white (89).

\section{The Gilgit Scouts and British Power}

The most important means by which the British ensured the collaboration of at least a decisive part of the Gilgit Agency's inhabitants - and perhaps the most ingenious instrument of power that they ever developed there-was the creation of the Gilgit Scouts Corps, a body of locally recruited paramilitary troops. In 1892, a year after the Hunza-Nager campaign, Algernon Durand raised a body of local military levies from Punial, Nager, and Hunza, thereby turning erstwhile enemies of the British into collaborators. The recruits ceased to be targets of British force and became elements and instruments of British power. Durand himself explained the feasibility of this scheme with the character of the people's "race" and their psychological constitution of being not "warlike" but "peaceful" (1899/1977, 206-8). The levies were called out for training one month of the year and remained in their villages the rest of the time. "[T]o impress on the men the very important fact that they were the servants of the government of India all the year round" (Amar Singh Chohan 1984, 193), they received regular pay every month. In 1913 the military levies were turned into the Gilgit Scouts. The number of recruits increased, and their training was intensified. The Gilgit Scouts consisted of eight companies of eighty men each. There were two companies each from Hunza and Nager and one company each from Yasin, Gupis, Punial, and Gilgit. When the British leased the Gilgit Tahsil in 1935, the Gilgit Scouts were transformed into a permanent body and replaced the Imperial Service Troops at Gilgit.

The local levies and Gilgit Scouts were not raised for military purposes only. Much more importantly, they procured an intimate bond between the British and a considerable part of the population. In the course of revisions of the scheme of levies and scouts, this intimacy was constantly extended. For instance, the time spent with British officers for training was prolonged, the number of scouts under training at one time was reduced, and finally in 1935 the scouts were converted from a part-time to a full-time troop. The effect of the Gilgit Scouts scheme can be understood best by employing the Foucauldian concept of discipline. According to Foucault (1979a), discipline should not be seen primarily as repressive and negative, but as transformative, even educative, enabling the management of the subject population (see also Hindess 1996, 113-15). As members of the Gilgit Scouts Corps, the men of the Gilgit Agency were imparted with British visions of regularity, of command and obedience, of order, in short. Important for the intimacy with the British, however, was not only the time actually shared with them. Equally significant was the material remuneration for their services, as it made both the scouts and their dependents and relatives conscious of the boons of British rule (Amar Singh Chohan 1984, 196, 198).

To be a member of the Gilgit Scouts, in addition to all the material gains, was considered a great honor in a society in which questions of honor and rank were of the highest importance. The Gilgit Scouts both strengthened the bonds between the British and the population of the Gilgit Agency and also contributed to the loyalty of the rajas. Although recruitment into the scouts had to be sanctioned ultimately by a British officer, proposals for recruitment were made by the local ruler. Being favored 
by the raja was in most cases the sine qua non for recruitment. Thus, the mīrs and rajas gained an important instrument of influence, as they of course recommended their own relatives and followers. Furthermore, the positions of noncommissioned or junior commissioned officers in the Scouts Corps were usually filled with close relatives of the rajas or with members of other elite families. In hindsight, Shah Khan, one of the veterans of the freedom struggle of 1947, remarked that the Gilgit Scouts were

political bait to the local Chieftains, Mirs and Rajas. They were intentionally kept away from education but were frequently reminded of the generosity and liberality of the British Government who had conferred on them such a great honor as the Viceroy's Commission. A VCO [Viceroy's Commissioned officer] of the Corps was allowed to maintain a special tunic[,] his own horses, private servants and many other formalities deemed essential for the royalty. After the British officers, they were the most powerful people respected by the Government, public, Mirs and Rajas equally.

(quoted in Dani 1989, 312)

The scouts served to distinguish the British further from the Kashmiri. Although the state government bore a considerable part of the costs of the scouts scheme, it had no hand in the scouts' organization or any influence on their command (Amar Singh Chohan 1984, 195-96). The relations established by way of the scouts scheme between the British/elite families and ordinary men of the agency bypassed the Kashmiri administration completely.

In contrast to Kashmiri domination, British rule in the Gilgit Agency became in part "hegemonic." "Hegemony" here does not mean a body of legitimating ideologies produced by intellectuals that has the effect of ensuring the consent of the subalterns (see Gramsci 1971, 12). In Gilgit a rather more implicit shared understanding developed out of a body of practices that gave the British not only an unassailable position but also an aura of being of a similar, even if superior, kind ("the same, but not quite"). Certainly not all sections of the population agreed to this hegemony; thus, British rule did not become hegemonic in a general sense as defined by Ranajit Guha in terms of persuasion outweighing coercion $(1997,23)$. But, those subjects of the British who shared this "practical hegemony" because of their involvement with the colonial masters through serving in the Gilgit Scouts Corps or assisting them in hunting expeditions or in their explorations of geography and local culture regarded the British as benevolent elders rather than as illegitimate usurpers of power. ${ }^{11}$ Their local servants executed for the British the roles of mediators or "deputies," similar to the function of intellectuals in the Gramscian model of hegemony designed for Western society.

Two elements are crucial for this hegemony. The first is the distinction between the British and Kashmiri, which allowed for the perception of the British in a very different way by the local population, although they too represented a foreign dominating power-even more than the Kashmiris did. The second element is a kind of cultural consensus established by shared values and practices that subjects could read as a British affirmation of local lifeways and virtues. In particular, the keen interest of British officers in polo and hunting could only mean that they shared the local values and virtues of manliness. Last but not least, many British officers took a deep interest in local culture and languages, which found its expression in numerous books and reports. This interest was certainly not completely innocent but contributed to

${ }^{11}$ At the time of my fieldwork, many children of former servants of the British as well as aged veterans of the Gilgit Scouts still spoke with high esteem of the former masters and especially their engagement in hunting, mountaineering, and playing polo. 
making British rule "smooth" - that is, more adaptable to local circumstances. ${ }^{12}$ The role that religion played in emphasizing the difference between the British and Kashmiri and in fostering an understanding between the British and their local subjects is not entirely clear. Sometimes British officers remarked that the Kashmiri "kafirs" were despised by the Muslims of the agency, but after all, the British themselves were not Muslim believers either. During World War I, the British feared religiously motivated revolts against their rule (Sökefeld 2002). One matter at least was crucial: slaughtering cows was prohibited by the maharaja's law. This rule was resented very much by the Muslim people of the agency, especially because it was sanctioned with severe punishment (Usman Ali 1990, 98-99).

\section{Tensions of Domination: Protest and Resistance}

Practical hegemony was not total in the Gilgit Agency. The people perceived and resented oppression and exploitation, especially the various practices of appropriating agricultural produce and bēgār, or kar bēgār (forced labor). These exploitative practices were not invented by the British, but rather were inherited from previous systems of domination. Under both local rajas and Kashmiri rule, the burden of taxes and bēgār had been excessive (Usman Ali 1990, 28-36). Bēgār was rendered especially for transport purposes but also in the context of military activities. Before the British extension of the road via Astor to Kashmir facilitated transport by pack animals, all supplies had to be carried by porters from Kashmir to Gilgit. This service was not only very arduous and dangerous but moreover kept the people from their agricultural work. British reporter E. F. Knight criticized the Kashmiri for "the unnecessary inhumanity with which the begar has been conducted on the Gilgit road [which] has driven the inhabitants to desperation, compelling them to fly from their homes, and thus still further diminishing the scanty population" (1893/1991, 285). This criticism implies that the British, in contrast, were more "human" in their demand for forced labor and employed bēgār only insofar as it was "necessary." The British, however, were not "humane" to the extent of abolishing this practice. They too required forced labor for transport, and they established regulations concerning which village was to supply how many men for what distance of travel. British officers were content to record complaints by the people against bēgār drawn by Kashmiri authorities, but this certainly does not allow the conclusion that the same people carried British loads voluntarily.

The case is the same for complaints about heavy taxation and the draining of agricultural produce. For instance, Political Agent B. E. M. Gurdon noted: "I have received complaints from some of the zemindars that the state officials compel them to furnish the supplies, required by them for their private consumption, at rates considerably lower than those prevailing in the open market. They also complain of excessive kar begar and the petty tyranny practiced by the police" (Gilgit Diary, July 1905, OIOC, L/P\&S/7/180/1397, n.p.). Besides regular taxation, farmers were forced to sell part of their produce at very low, nonremunerative rates which were fixed by the administration. Hukmi khārìd (ordered purchase), as it was called, was practiced

\footnotetext{
${ }^{12}$ Although local knowledge was crucial for the British mode of domination, not all knowledge was collected directly for administrative purposes. The most obvious example of this is D. L. R. Lorimer, who, having been a political agent, returned years later to the agency without any office to complete his studies of the Burushaski language.
} 
and sanctioned by the British as much as it was by the Kashmiri. To ensure the provisions of the Gilgit garrison, farmers were forced to supply grain, in addition to milk, eggs, and chicken (the rēs system), to feed the officers.

When "native" officer Thakur Singh compiled the "Assessment Report for the Gilgit Tahsil" in 1917, he recorded much protest against these services, regardless of whether they were required by the British or by the Kashmiri authorities. He noted: "The system heavily tells upon the supplier zamindars, who have been feeling no small hardship and burden upon them, in as much as they are required to supply milk by way of Begar under most pressing circumstances" (1917, 42). Even though the British officers knew well that these exploitative practices were a heavy burden for the people, his recommendation to abolish hukmī khārīd was turned down (93). The supply and transport officer on special duty in Kashmir simply remarked in 1915: “A Kashmiri will not stir without a 'Hukm' [order], and still less, I believe, an inhabitant of the Gilgit Agency" (quoted in Thakur Singh 1917, 161). The real problem, then, was the perceived laziness of the people; British pressure and orders were just the remedy for this evil. ${ }^{13}$

Framed in these terms, hukmī khārīd (as well as bēgār) could well be understood and justified as part of the overall British civilizing mission: it disciplined the colonial subjects. The resident in Kashmir, somewhat contradictorily, came to the cynical conclusion that all these "hardships" were no actual hardships for the people of the agency because they were long accustomed to them and simply did not know otherwise (Thakur Singh 1917, 93). Although Maharaja Hari Singh abolished bēgār in Kashmir in 1933, it continued to be practiced in the Gilgit Agency-and also after the lease of the agency by the British in 1935 (Usman Ali 1990, 32).

From these source emerges a rather different picture: an image of constant tension between British officers and their subjects, who had no choice but to supply them with labor, grain, eggs, milk, and fowl, without proper return. At least on one occasion, the British used force to quell resistance to bēgār. In 1940 unrest in Yasin reached a stage which required the Gilgit Scouts to put down the protest and arrest twelve leaders ("Administration Report of the Gilgit Agency," 1940, OIOC, L/P\&S/ $12 / 3288$, p. 6). This was not the only occasion when the British were confronted with protesting voices of the people of the Gilgit Agency. Such events were always framed in British records as matters of dissent between local rulers and their subjects. Interestingly, the British were often addressed as arbitrators by protesting peasants. Earlier, in the winter of 1937-38, deputations from a number of villages in Hunza and Nager came to see the political agent in Gilgit to appeal for redress: those from Nager (from the villages Bud, Budelas, Chalt, Chaprot, Sikanderabad, and Yal) protested the excessive demand for bēgār and taxes by the mîr and the other members of the royal family, whereas the delegates from Hunza (from the villages of Mayun and Hindi) complained about the appropriation of land by the mîr. In both cases, the political agent refused to act on behalf of the peasants. Both cases were explained with reference

\footnotetext{
${ }^{13}$ Thakur Singh too subscribed to the thesis of the "laziness" of the inhabitants of Gilgit, who seemed to care only slightly for their fields, but also supplied a possible explanation for their apparent neglect of agricultural work: "The people of Gilgit, unlike those of HunzaNagar and Skardu, are generally lazy and appear to take not much pains in cultivating their lands. They have no liking for manual labor. . . A Another difficulty, that perhaps stands in the way of the people attending to their fields properly, appears to be the burden of Kar-begar. With the exception of ploughing and other hard duties the work of agriculture is mainly left to womenfolk" $(1917,65)$. Of course, if the men were kept busy with bēgār, they had to leave work in the fields to the women (see Usman Ali 1990, 32).
} 
to local rivals of the mīrs. That is, the peasants protested because they were incited to do so by Raja Khisro Khan (in the case of Nager) and Qudratullah Beg (in that of Hunza); they did not come only because they were exploited (Gilgit Diary, January 1938, OIOC, L/P\&S/12/3285).

Similar events had already occurred in 1930. In February of that year, delegates again from Hindi and Mayun came to Gilgit to register their complaints about what they considered an increased and unjustified demand for bēgār by the mīr of Hunza (Gilgit Diary, February 1930, OIOC, L/P/10/973). The administrative report of the year recorded: "Some disgruntled zamindars of Hini [Hindi] and Mayun started an agitation against the Mir, protesting that he was imposing new burdens upon them not recognized in established custom. The agitators are not true Hunzawals of the Mir's own clan but Shinakis originally from Gilgit direction, and have ever been less loyal to the Mirs of Hunza" ("Administration Report of the Gilgit Agency," 1930, OIOC, L/P\&S/12, 3288, p. 2). ${ }^{14}$ For the British, then, the matter was simply one of loyalty toward the mir - without regard for the fact that the inhabitants of Shinaspeaking villages of lower Hunza were taxed at a much higher rate than the Burushaski-speaking population of central Hunza (Kreutzmann 1996, 283) and that consequently it would have been much more plausible to understand the issue (including the supposed disloyalty) in terms of exploitation by the mīr. The protest of a delegation from Nager in March 1930 was framed in similar terms (Gilgit Diary, March 1930, OIOC, L/P\&S/10/973).

From these sketches of dissent as registered in British records, the peasants appear to have very well understood the structure of domination in the Gilgit Agency. British power personified by the political agent guaranteed the position of local rulers as long as they did not interfere with British interests. Accordingly, redress from excessive exploitation by the rulers could only be hoped for by way of the intervention of the political agent. The British warranty of power for the local rulers was also responsible for the rajas' and mīrs' ability to draw bēgār and demand taxes in excess. No rival powers were left within the petty states that could endanger the position of the rulers or that would have forced them to seek the consent of their subjects. Another conclusion which can be drawn from the reports of protest in British documents is that the British themselves never felt endangered or even challenged by these events. From their perspective, they ruled out the dissent because it was unjustified in terms of local rules and custom (Gilgit Diary, January 1938, OIOC, L/P\&S/12/3285).

\section{Transition of Power, Crumbling of Domination: Events in 1947 and 1948}

The self-image of benevolence and paternal rule cultivated by the British culminated on the eve of their retreat from the Gilgit Agency in 1947. According to a young British officer, this self-image emerges with such overdrawing that now, more than fifty years later, it can be read almost as a parody:

Until the official from Kashmir actually arrived in Gilgit, the people of the Agency would not believe that the British were leaving them. Their faith in us was unshakeable_-they could not believe that we would desert them and hand them over to a rushaski.

14"Shinakis" are speakers of Shina, whereas the population of central Hunza speaks Bu- 
bunch of Hindu babus. Even after they had been given the details of the changeover, they did not seem to grasp the full significance of what it all meant to them and their lovely valleys.... To illustrate the feelings of the tribesmen in the Agency at the time of handing-over, I will here describe briefly the handing-over ceremony that took place in Chilas, the most turbulent and ungovernable part of the Agency. Thousands of tribesmen had foregathered in the compound of the Fort at Chilas. The Scouts Guard of Honor were drawn up smartly at the foot of the flagpole. Officials from Kashmir and Gushpur Muzaffar Khan (representing Captain Hamilton, APA [assistant political agent], who refused to take part in such an ignoble ceremony) were present. The Union Jack was fluttering from the flag staff over the Fort for the last time. The tribesmen, fierce, rugged as the mountains amongst which they live, menacingly fingered long knives, axes, and antiquated matchlocks. At one word from Captain Hamilton they would have cut down those Hindus present and torn up the Kashmir flag. But without his approval they would have done nothing. The Guard of Honor again presented arms to the Union Jack and the thousands of tribesmen present broke into great cheers for the British Raj. Many of these hardy warriors, accustomed to acts of unparalleled cruelty, broke down. Slowly the Union Jack was dragged to the ground. The Guard of Honor again presented arms-this time to the green and yellow emblem of Kashmir. The Hindus present called for three cheers for the Maharaja. But no answering shout greeted them. Only the noise of a distant thunder was heard as the mighty tribesmen turned their backs and, cursing and threatening, returned to their mountain valleys. We have deserted a most loyal and noble people. May those responsible live to rue the day!

(Gilgit Diary, OIOC, L/P\&S/13/1860, pp. 57-59)

The words and phrases used in this statement are indeed remarkable. That the British left the Gilgit Agency was not a matter of liberation, but of deserting their most loyal subjects. All these subjects seem to have done nothing but enjoy British rule (contrary to the many British reports of unrest especially from the region of Chilas). If even the fierce tribals of Chilas and the Indus Valley cheered for the British raj, how much more heartwarming must the reaction have been of the more refined and almost civilized inhabitants of Gilgit, Hunza, or Nager? Even nature registered its disapproval of the British departure by a "distant thunder." We are assured that the relationship between British rulers and local subjects had an almost religious dimension; it was a matter of "unshakeable faith." The description earlier of Political Agent Algernon Durand resonates here-that the political agent's "voice must be hearkened to and obeyed, as if it were the voice of a god." Certainly these "believers" in British power would have killed the Kashmiris present at the ceremony in Chilas at the word of their officers, and it was equally certain that they were paralyzed and unable to act without such a word.

Even if these sentences of a disappointed British officer cannot be taken at their face value, the fact remains that there was nothing like a Quit India Movement in the Gilgit Agency. People were much more alarmed by reports about violent HinduMuslim conflicts in India than about the issue of British rule or freedom (Sökefeld 1997b, 266-67). What seemed to matter most was not the question of whether the British left, but what was to come after: India or Pakistan. The independence movement in India had been divided into two factions, one led by the Congress Party with Jawaharlal Nehru and Gandhi, the other by the Muslim League under Mohammad Ali Jinnah. Mohammad Ali Jinnah promoted the idea that there were two nations in the subcontinent: a Hindu nation and a Muslim nation. According to this two-nations theory, these two nations differed to the extent that they could not live together in a single independent state (see Jalal 1985; Hasan 1993; Talbot 1996). Therefore, Mo- 
hammad Ali Jinnah demanded the partition of the subcontinent into a state for Hindus (India) and one for Muslims (Pakistan). When the British accepted this demand, partition took place. Muslim majority areas were to become Pakistan, while regions with a mainly Hindu population formed India. In princely states, the rulers could decide for either India or Pakistan. Normally they had the same religious affiliation as the majority of their subjects. In Jammu and Kashmir, however, both principles contradicted one another, as a Hindu maharaja ruled over a Muslim majority population. For the time being, Maharaja Hari Singh decided neither for India nor for Pakistan. Yet, the people of Gilgit, who all were Muslims except for a small section of Kashmiri Hindus, clearly favored joining Pakistan.

The British gave control of the Gilgit Agency to the maharaja of Kashmir, who, during the following months, remained undecided himself. A Kashmiri governor, Brigadier Ghansar Singh, was sent to Gilgit but was unable to establish power. He lacked both the consent and the force to do so. The Gilgit Scouts, who before had been a crucial instrument in the British continuation of power, became now a power in themselves - a power aiming with increasing determination at the establishment of a Pakistani administration in Gilgit. From all we know about the British-Kashmiri rivalry in Gilgit, it was foreseeable that the officers of the Gilgit Scouts would not readily serve a Kashmiri administration. It is still surprising, however, how selfassuredly the officers faced Governor Ghansar Singh in their very first meeting. The governor's report converges with the story told by Subedar Major Babar Khan, the most senior local scouts officer: on the day of Ghansar Singh's arrival, Babar Khan and his companions told the governor that they wished for Gilgit to become a part of Pakistan. The governor was confronted with a list of demands by the Gilgit Scouts, summing up the conditions under which they were ready to serve the maharaja (Ghansar Singh 1983, 25-26). Safiullah Beg, one of the veterans of these events and at the time a subedar of the Gilgit Scouts, recounted that the first demand was that the Gilgit Scouts, still a "civil armed [i.e., paramilitary] force," should become regular members of the Jammu and Kashmir State Forces (interview, February 24, 1992). The demand sounds more opportunistic than political; according to Babar Khan's report, however, this condition had definite political significance. Babar Khan complained that although the great majority of the state's population was Muslim, Muslims were greatly underrepresented in the State Forces. Ghansar Singh justified this state of affairs with the argument that Muslims were no "martial race" and that they were accordingly not fit for military service. To this, Babar Khan replied: "If the Muslims of Kashmir do not belong to a martial race, we inhabitants of Gilgit can correct this shortcoming" (Babar Khan 1973, 27). At stake here, then, was discrimination against the majority of Muslims within a Hindu-ruled Jammu and Kashmir State. Ghansar Singh was unable to fulfill the demands of the scouts but agreed to forward them to the maharaja, promising to have an answer within a week. ${ }^{15}$

Besides the Gilgit Scouts, regular Jammu and Kashmir State Forces were also posted in the area. Their garrison was in Bunji, the place on the eastern banks of the Indus River which during the time of the British lease of the Gilgit Agency had marked the border of Kashmir territory. These troops consisted of a Sikh and a Muslim company. When Ghansar Singh arrived at Gilgit, the Sikh company was called there.

${ }^{15}$ According to Ghansar Singh's report, similar demands were made the following day by the civil employees of the agency. They too declared their wish to join Pakistan but said that they were ready to serve the maharaja under the condition that their salaries were raised (1983, 26). 
The governor wanted the Gilgit Scouts to evacuate the Gilgit barracks and have the State Forces stationed there instead, but the Gilgit Scouts refused to leave. The State Forces had to camp on the new polo ground in Gilgit (Babar Khan 1973, 26). According to a number of witnesses with whom I spoke in 1992, the people of the town very much resented the comportment of the Sikh soldiers. They allegedly washed themselves half-naked in the water channels and walked around in the fields, thereby obstructing the agricultural work of the women who were not supposed to be seen by strangers. When the scouts continued to refuse to evacuate the barracks, the State Forces returned to Bunji to prevent open conflict.

Ghansar Singh's assessment of the public opinion at the time of his takeover appears to have been only wishful thinking: "The general impression was that the British officers did not like the change over, but the Gilgit public, however, was highly pleased with the transfer of power and they welcomed the change. .." (1983, $25)$. We can infer that indeed many officers were resentful of having to depart the agency; however, it still seemed that in contrast to the people of Gilgit, they thought it natural and correct that the agency was given to Kashmir and not to Pakistan. At one point, Babar Khan criticized Political Agent Major Roger N. Bacon for not having inquired about the Gilgit Scouts' opinion on the future of the agency, to which Bacon simply answered: "[L]ook, this is a part of the State. ." (1973, 26). Apparently the maharaja also regarded the British as guarantors of the integration of the Gilgit Agency into Jammu and Kashmir State, for he appointed two British officers, Major William A. Brown and Captain Jock Mathieson, as commanders of the Gilgit Scouts.

By the end of August, the maharaja's reply to the demands of the scouts had still not arrived. Several times the governor tried to hold an oath-taking ceremony in which the Gilgit Scouts were to swear their loyalty and allegiance to the maharaja, but the scouts refused to take the oath unless their demands were fulfilled. Secretly the officers of the Gilgit Scouts and important civilians made preparations for accession to Pakistan. On the occasion of the darbār in mid-October, when not only the rajas but also the officers of the State Forces' companies of Bunji were present in Gilgit, the officers of both the Gilgit Scouts and the Muslim company of the State Forces met and took an oath that they would risk their lives to make the Gilgit Agency part of Pakistan (Syed Durrani 1985, 377). When it had become known that, under the pressure of several uprisings and the invasion by Muslim warriors, Maharaja Hari Singh had declared on October 27, 1947, the accession of Jammu and Kashmir State to the Indian Union, the freedom struggle in Gilgit began.

The subsequent events, which I have analyzed in detail elsewhere (Sökefeld 1997a), shall be summarized here: Ghansar Singh was arrested, the Muslim soldiers of the Bunji garrison sided with the Gilgit Scouts regarding Pakistan, and the Sikh company fled into the mountains. Also, the two British officers of the Gilgit Scouts, more or less uneasy, supported the case for Pakistan. In Gilgit a provisional government of the "Islamic Republic of Gilgit" was formed, which invited the Government of Pakistan to take over the administration. On November 16, Mohammad Alam, representing Pakistani authority, arrived by plane and assumed office as political agent. Hastily, all available men were recruited into the newly formed "freedom forces," which advanced toward Kashmir and Baltistan and fought against Indian troops. On January 1, 1949, a ceasefire was called after the mediation of the United Nations. As a result, a considerable part of former Jammu and Kashmir State came under the influence of Pakistan either, as in the case of Azad Kashmir, under a formally independent government that nevertheless depended heavily on Pakistan or, in the 
case of the Gilgit Agency and Baltistan ("Gilgit Baltistan"), directly controlled by the Government of Pakistan.

\section{Pakistani Rule in Gilgit: A New Colonial Situation?}

Although apparently successful, the officers of the Gilgit Scouts did not achieve what they had sworn to stake their lives for. Gilgit has not, to this day, become de jure a part of Pakistan. During the very first days after the arrival of Political Agent Mohammad Alam, it became obvious to the local leaders of the freedom struggle that their ideas of freedom did not match those of Mohammad Alam. He deprived them of all authority and competence. It remains unclear to what extent the ensuing difficulties between the political agent and the local officers-especially Captain Hassan Khan, the commandant of the Muslim company of the State Forces at Bunji who had become "commander in chief" of the insurgent troops-were due to political differences concerning the question of self-determination in the Gilgit Agency or simply to a disillusionment of personal ambitions (for details, see "Precis of the Events in Gilgit since the Arrival of Sardar Mohd Alam, Political Agent," OIOC, L/P\&S/13/ 1860; Sökefeld 1997a). It probably was a combination of both. Also, the military command was taken by a "Pakistani" officer, Colonel Aslam (aka Colonel Pasha), who came from what had become Azad Kashmir. The Gilgit Scouts and the other local military involved had risen from subalterns to a dominant power, but now they were to become subalterns again.

In the beginning, things had seemed to be very different. The people in Gilgit had succeeded in putting an end to Kashmiri rule in their area. A Pakistani administration in Gilgit was installed. Major Brown described the joy of welcoming Mohammad Alam, the man who was to establish Pakistan, to Gilgit:

He was given an enthusiastic welcome by the local population and escorted in triumph to the Agency House. In a few well chosen words he exhorted the people to cast aside their faction feeling and unite as one in the cause of Islam. This short speech was greeted with further burst of enthusiasm before the crowd gradually dispersed. On the 17th November at 9.30 a.m. the Pakistan flag was hoisted on the flag pole at the Agency House whilst a Guard of Honor from the Gilgit Scouts paid full honours and the pipes and drums played the Royal Salute. Large crowds turned out to watch the ceremony and the intense approval of all was very noticeable.

("Precis of the Events in Gilgit since the Arrival of Sardar Mohd Alam, Political Agent," OIOC, n.p.)

On the next day, however, the political agent made clear to the insurgent officers that the command was now his. Slowly, many people realized that the aims of their struggle would not achieve fruition in the new administration; British reports claimed that Mohammad Alam did not meet the expectations of the people of Gilgit (see "C. B. Duke, High Commissioner for the UK, Peshawar, Based on a Report of Maj. Brown after Leaving Gilgit," January 19, 1948, OIOC, L/P\&S/13/1860). Not only had the scouts become subalterns again, but all the exploitative colonial practices that the people had constantly resented were also continued by the new administration.

During the freedom struggle, the people had been willing to continue paying taxes to support the actions of the scouts, as Usman Ali notes (1990,123). But after 
the war, practices such as bēgār, rēs, and heavy taxation were not abolished. In most parts of the Gilgit Agency, the mīrs or rajas remained autonomous in internal affairs and continued their despotic rule. Usman Ali summarizes: "We inherited all evils of the times of Dogras and the British: FCR [Frontier Crimes Regulation, a special procedural law], taxes, raja rule, hukmī khārīd, bēgār, the trouble of rēs, all this was in one or another form preserved" (1990, 132; on the FCR, see Sökefeld 1997b). These continuities provoked growing alienation between the people and the new administration.

In Gilgit a number of people started to protest certain practices of the new administration regarded as unjust, including bēgār and taxation. The protest was silenced in the name of Islamic unity (which apparently did not allow for dissent with the rulers), and the leaders of the protest were arrested. The Gilgit Scouts continued to serve the dominant power. In 1951 residents of Punial protested the taxation by the raja (Qudratullah Beg 1967, 82). When the demonstrations did not stop, the raja of Punial ordered some of his followers to shoot at the unruly people. Six persons were killed. Immediately, a section of Gilgit Scouts was sent to arrest not those who had opened fire, but those who had dared to express their discontent (Qudratullah Beg $1967,83)$. At the end of the 1960s, a large resistance movement against the despotism of the mīr of Nager demanded the reduction of bēgār and taxation as well as certain participation of the residents in the public affairs of Nager. Again, the scouts were sent against the people. After shootings at a demonstration at Chalt in Nager in 1970, nine persons were killed and many more wounded. The leaders of the protest were imprisoned (Sökefeld 1997b, 282).

After these events in Nager, many people were shocked that the Gilgit Scouts, who were still regarded as a force of freedom, had turned violently against the people. Some of the members of the Gilgit Scouts too had reflected upon their role. In the beginning of 1971, a large protest movement emerged in Gilgit, leading to a general strike (for details, see Sökefeld 1997b, 284-89). When people started to attack the police station and the prison to liberate their arrested leaders, the scouts were ordered by their nonlocal (Punjabi and Pashtun) officers to shoot into the crowd. This time, however, the scouts refused to obey the command and either fired only into the air or refused to shoot at all. Locally, these incidents are sometimes called the "revolution of Gilgit" (inqilāb-e Gilgit). Troops from the North-West Frontier Province-that is, nonlocal troops-were called in to end the insurgency. Soon after, repression gave way to a period of reform when, during Zulfiqar Ali Bhutto's term as prime minister and later as president of Pakistan, the administration of the Northern Areas changed in a number of significant ways. Taxation, bēgār, and raja rule were abolished. The region now called the "Northern Areas" seemed to be on the verge of becoming a regular province of Pakistan. The reforms ended, however, when General Zia ul Haq took power in 1977.

A last significant action of the Gilgit Scouts that occurred under the administration of Zulfiqar Ali Bhutto should be narrated. After 1972 society in Gilgit became increasingly torn by a militant conflict between Shiites and Sunnis. Allegedly this conflict was originally instigated in Gilgit by the government to break the unity of the people. When in the beginning of 1975 the Shiite mubarram (mourning) procession was shot at from the Sunni main mosque in Gilgit, the Sunni qāzi (head of the main mosque) was arrested by the deputy commissioner. A force of armed Sunnis moved toward Gilgit from the southern parts of the Northern Areas to liberate their leader. Once the Shiites found out about this advance, they marched in arms from Nager toward Gilgit. To prevent an imminent clash, the Gilgit Scouts marched out 
and stopped both the Shiites and Sunnis before they reached the town. Soon after that, the Gilgit Scouts were dissolved; a new troop was installed, the "Northern Light Infantry" (NLI). The Gilgit Scouts had always been a body of locals under the command of nonlocal officers, but in the new (regular) military body, local soldiers were mixed with nonlocals. That is, for the first time, no local armed force existed in the area. Many people in Gilgit whom I interviewed drew a connection between the alleged governmental instigation of Shiite-Sunni tensions and the dissolution of the Gilgit Scouts. Although it seems far fetched, they suggested that the scouts were abolished because they had prevented a religious war and thus obstructed a divideand-rule strategy. Those who entertain such a suspicion see their opinion reaffirmed by events in 1988 when a Sunni armed force violently attacked Shiite villages close to Gilgit and was in no way hindered by the regular army - a local force that could have impeded the ensuing atrocities like the scouts had done in 1975 no longer existed.

During the military rule of Zia ul Haq, oppositional political action in Gilgit was almost impossible. But since the late 1980s, a number of political groups have been formed by people of the area which aim at improving the unsatisfactory political and constitutional status of the Northern Areas. This development is also due to general political liberalization since the end of the dictatorship. One consequence of this liberalization was that political discrimination became utterly visible: a number of general elections have been held since the death of $\mathrm{Zia}$ ul Haq in 1988, but the inhabitants of the Northern Areas have never had the right to cast their votes because the Northern Areas is de jure not a part of Pakistan. The new political organizations of the Northern Areas became the bearers of a nationalist discourse, asserting a distinctive national identity of the Northern Areas in contrast to Pakistan (Sökefeld 1997b, 301-9; 1999). ${ }^{16}$ Thus, the idea of national unity with Pakistan, conceived originally on the basis of the assumption of a Muslim nation in South Asia as formulated by Mohammad Ali Jinnah in his two-nations theory, was discursively challenged. In the body of texts and speeches constituting this nationalist discourse, the Pakistani administration of the Northern Areas is termed explicitly a "colonial" (nau$\bar{a} b \bar{a} d \bar{\imath} a t \bar{\imath})$ system. ${ }^{17}$

Since 1992, oppositional groups have refused to celebrate November 1, the anniversary of the beginning of the freedom struggle, as "freedom day." They celebrate instead a "day of martyrs" (yōm-e shuhada). For August 14, 1997, the fiftieth anniversary of the independence of Pakistan, which was to be commemorated all over the country, members of these groups planned a huge demonstration against this, in their opinion, "black day" for the Northern Areas. But, their plans could not be carried

\footnotetext{
${ }^{16}$ It is quite difficult to assess the strength of nationalist oppositional parties such as the Balawaristan National Front or the Karakorum National Movement in terms of membership because for political reasons there are no formal provisions such as member lists or regular fees. Activists are present in many villages besides Gilgit, however, and the groups are able to mobilize so many people for demonstrations and other activities that the administration considers them a danger. A few party leaders have developed quite a high profile in the media.

${ }^{17}$ Referring to the resolutions of the UN Commission for India and Pakistan (UNCIP), which provided for "local rule" in Gilgit-Baltistan, one activist draws the following comparison: "It was clearly mentioned in the resolution . . . that the area will be administered by the local authorities under the surveillance of the commission but, the Govt. of Pakistan occupied this area just like East India Company making it a colony violating the UNCIP's resolutions and this fraudulent occupation is continued since last half century" (Amir Hamza n.d., 2). For a book-length interpretation of the history of the Northern Areas in terms of Pakistan's colonialism, see Abdul Hamid Khan 2001.
} 
out. The day before, a number of oppositional political leaders were arrested, and more were detained on August 14 while gathering in the center of Gilgit. The demonstration was prevented by police force. Altogether, about sixty oppositional activists were arrested and, accused of treason, remained in detention for several weeks. Some of them were seriously mistreated while under arrest. This was not the first time that an oppositional demonstration was dissolved by force. Very often, section 144 of the Pakistan Criminal Procedure Code is enforced in the Northern Areas, prohibiting assemblies of more than four persons and providing the legal means for the prevention of political action unpopular with the government.

Another violent event had occurred in June 1996. A new body of "Northern Scouts" had been planned by the administration. These Northern Scouts were to enlist mainly local young men. Unemployment is a major problem in the Northern Areas (as generally it is in Pakistan). Public administration is the major employer in Gilgit, but due to a halt of recruitment there had been no new opportunities for employment in a number of years. ${ }^{18}$ Recruitment for the "Northern Scouts" was scheduled for June 22 at Gilgit College, and several hundred young men were determined to participate in the interviews. A body of Chitral Scouts originally stationed in Gilgit to prevent sectarian tensions was to secure an orderly procedure. When, after hours of waiting, some applicants expressed their impatience, they were beaten by the Chitral Scouts. In reaction to this, a man hurled a stone at the scouts, and then the events came thick and fast: the crowd pushed against the scouts, who opened fire, killing one man and injuring six others. When news of the incident spread through the town, people gathered in the streets and shops, and offices were closed in protest. A large crowd moved toward office buildings, and several were set on fire. Police resorted to teargassing the crowd, and the army was called. A curfew was imposed, and several politically active persons were arrested. Gilgit had been under curfew many times before due to sectarian tensions, but this was the first time that a curfew was imposed because of more politically motivated incidents. Two days later, a large delegation of persons from the Northern Areas visited the office of the UN Commission for India and Pakistan (UNCIP) in Islamabad and handed over a memorandum addressed to the UN secretary-general condemning the attitude of the Government of Pakistan toward the area and demanding the implementation of the UN Resolution on Kashmir of August 13, 1948, which had demanded "local self-rule" for the regions affected by the Kashmir dispute. This memorandum explicitly lamented the "colonial' and 'apartheid' policy followed by Pakistani rulers" (for the full text, see Muslim, June 25, 1996).

Compared to the British mode of domination in the Gilgit Agency, the Pakistani mode exhibits rather the opposite trajectory. The British had to exert effort to establish a measure of consensus and partial hegemony after they had taken control of the area. With their experienced skill of "wise" rule, the British achieved their goal remarkably well and masked their colonial control with a camouflage of cultural adaptation and distribution of honor, rank, and subsidiary power. The partial "practical hegemony" achieved by the British was decisively aided by their ability to compare favorably with the worse colonial practices that had been executed previously by the Kashmiri

${ }^{18}$ Public employment has for some time been a significant matter of political discontent. Allegedly most posts, especially those of higher grades, go to "outsiders" - that is, to persons from the North-West Frontier Province and the Punjab. The issue became even more heated when in 1985 the salaries of only nonlocal employees were augmented by 25 percent (Sökefeld 1997b, 299-300). 
administration. Although the colonized population constantly criticized exploitative practices such as bēgār and hukmī khārīd, available British sources do not present the picture that such protest ever entailed a challenge to British colonial control as such. Paradoxically, it seems that these practices were identified as colonial practices only in retrospect, when, in spite of all the rhetoric of Muslim unity and freedom, these muchresented practices were continued by the Pakistani administration.

Pakistan's control of the Gilgit Agency and the Northern Areas, in contrast, started with a high degree of legitimacy and consensus, but this credit was rapidly spent and rarely renewed. Consequently, Pakistani power in the area increasingly depended on (or was replaced by) force. In contrast with the British, the Pakistani administration did not pay particular attention to local values and customs. Until Zulfiqar Ali Bhutto's term, the Pakistani administration never attempted to build a consensus or secure the legitimacy of its rule in the Northern Areas. Again, under military rule after 1977, legitimacy was no issue. The legitimacy of Pakistan's position in the Northern Areas was simply taken for granted by virtue of a shared Muslim nationhood and of "national interests" in the context of the Kashmir dispute. In Gilgit, however, the Pakistani administration was increasingly regarded as foreign domination. The idea of national self-determination that once motivated the struggle for independence, partition, and accession to Pakistan was now turned against Pakistan.

Distinguishing between colonialism as structure and colonialism as signification-that is, between a system of actual rules, institutions, and practices of domination by a foreign power, on one hand, and its local perception and interpretation, on the other-we can say that the Pakistani administration from its inception continued colonialism as structure. The rules of administration in Gilgit were not changed, and power was not given over to local hands: only the British political agent was replaced by a Pakistani one. In the beginning, however, this structural continuity was hardly reflected in signification. ${ }^{19}$ Pakistani colonialism in the Northern Areas became a matter of signification only after people in Gilgit understood that Pakistani control of the area was to be continued by force despite the erosion of consensus and legitimacy and after the local population started to resent this control strongly-that is, when colonialism as structure surfaced to an extent that it could not be dissimulated. We can identify the "revolution of Gilgit" as such a turning point. In its aftermath, both colonialism as signification and colonialism as structure rapidly declined in consequence of the reforms of the Bhutto era. With the abolition of colonial practices and regulations such as bēgār, taxation, and the FCR, Pakistani administration achieved a very high degree of legitimacy and consensus. Matters changed again during and after the rule of Zia ul Haq. Reforms ended, but at the same time an unprecedented access to education and dissemination of political knowledge in the area resulted in an increasing awareness of discriminating political conditions as well as a heightened ability to identify colonial relations explicitly. Since the beginning of the 1990s, colonialism as signification is more present in the political (oppositional/ nationalist) discourse than ever before. In this discourse, Pakistan's legitimacy of rule in the Northern Areas is almost completely negated, and demands for independence are raised. This challenge to Pakistani power and control has been answered with

${ }^{19}$ In this respect, the Pakistani administration was in the beginning similar to that of the British but was very different from Kashmiri rule of 1947: Ghansar Singh possessed nearly no actual control over the area, as he lacked all means of force to assert his position and almost had to dance to the Gilgit Scouts' tune. Colonialism as structure was nearly absent, whereas colonialism as signification was at its height. 
repressive force, curbing political activities and freedom of expression. Colonialism as signification engenders colonialism as structure again.

In contemporary nationalist writings, the Pakistani administration of the Northern Areas is sometimes compared unfavorably even with the regime of the maharaja of Kashmir. Some points of this comparison are that, in contrast to the Pakistani regime, the Kashmiri regime provided for the representation of the then Gilgit Agency in the state assembly, it enabled access to and right of appeal at the High Court, the Gilgit Agency possessed full status as a province of Jammu and Kashmir State, and via the "State Subjects Rule" it prohibited the employment of "foreigners" in the administration and the purchase of land by "foreigners" (see, for example, "Manshū" n.d., 6). ${ }^{20}$ Similarly, a pamphlet of the Balawaristan National Front, a nationalist party, states: "Historically non-Muslim rulers of J\&K, Hari Singh gave Balawaristan [Gilgit Baltistan] a provincial status. He did not get Muslims to fight among themselves in the name of communalism. He imposed 'State Subjects Rule' to protect historic rights of Muslims of $\mathrm{J} \& \mathrm{~K}$ and Balawaristan ... so that aliens may not infringe on the rights of locals irrespective of religion. Even today, that law is practiced in J\&K, but Pakistani rules have changed our paradise into the colony of Pathans by breaching State Subjects Rule" (n.d., 2-3).

The nationalist discourse of the Northern Areas offers fundamental dichotomies of the Northern Areas and Pakistan: Northern Areas/Pakistan, colonized/colonizers, subaltern/dominant, dependence/power, exploited/exploiters, victims/victimizers, legitimate struggle/illegitimate rule, and self/other. These dichotomies eclipse the previous unity/identity of both opponents in the name of Islam (thereby replacing previous oppositions such as Muslims/Hindus) and eradicate difference between categories. Contrary to the new nationalist vision (and maybe to my narrative of "postcolonial colonialism" in the Northern Areas), the construction of a singular subject position (in its dual sense) of "the people" of the Northern Areas vis-à-vis Pakistan presupposes the omission of a range of cross-cutting relations. The question of who the subalterns are in the Northern Areas is not satisfactorily answered as easily as the nationalist discourse would suggest. There is no clear-cut uniform structural opposition between the people of the Northern Areas and Pakistan. Relations of "collaboration" (to use that tendentious term) run across the proposed dichotomy. For instance, many locals are and were of course entangled in the Pakistani administration and in the military, but the nondichotomous character of colonial relations to which I referred in the beginning of this article is not reflected in nationalist discourse. The purpose of nationalist politics of identity is precisely to silence cross-cutting relations and emphasize the opposition of domination and subordination to enhance the legitimacy of its own struggle.

Take the example of the Gilgit Scouts. They have, even before the new nationalist discourse, attained the status of a "national" symbol. To achieve this position, certain aspects of the scouts' history had to be obscured. All the "postcolonial" texts referred to celebrating the actions of the scouts during the freedom struggle-for example, portraying them as a force of freedom-are characterized by the total eclipse of their

20"Foreigners" in the provision of the State Subjects Rule are all persons not registered as subjects of Jammu and Kashmir State. This rule is still enforced in today's (Indian) Jammu and Kashmir State and in Azad Kashmir but not in the Northern Areas. Accordingly, nonstate subjects such as those from the Punjab or Pashtun are in a position to buy land and be employed in the Northern Areas but not in Azad Kashmir. For a brief discussion of the State Subjects Rule, see Sökefeld 1997b, 122-23. 
colonial role: their function and instrumentality for British rule (see the texts referred to in Sökefeld 1997a; cf. Dani 1989, 312). The scouts seem to have come into being in summer 1947 only, as if they never had been called to repress opposition and resistance. The same is true for the role of the scouts under Pakistani command. ${ }^{21}$ The scouts' killing of demonstrators remains mostly an untold story. Perhaps it can be concluded that the scouts' achievement of a status as a national symbol was decisively aided by the abolition of that troop by the Government of Pakistan. ${ }^{22}$ The example of the scouts shows that the invention of a tradition may well consist mainly of the oblivion of a more complete history.

A very marked dichotomization of subalterns and (exploitative) dominants in pre1947 times is exhibited by one of the most important local histories of Gilgit, Usman Ali's Gilgit kè rōg kahān̄ (The Painful Story of Gilgit). Throughout his writings on pre-1947 history, Usman Ali constructs a very clear-cut opposition in which the British, Kashmiri, and local rulers (both before and after Kashmiri intervention) are equally the exploiters and oppressors of "the people." In fact, Usman Ali emphasizes the exploitative role of the local rulers and their relatives (gushpur r) who all demanded their share of taxes and bēgār, but he does not reflect upon the fact that the officers of the Gilgit Scouts as well as the most important officer of the Kashmiri Muslim company (Colonel Hassan Khan), belonged to the same oppressive class. How is it that they (inadvertently?) were turned into heroes of freedom? Usman Ali offers no explanation. When he remarks that the "revolutionary passion of the people" who still felt the "wounds of local raja rule on their bodies" destroyed the aspiration of the rajas for the restoration of their power $(1990,129)$, he obviously excludes the insurgent officers from the aspiration of these rajas. At least some reports about the conflicts in the weeks following November 1, 1947, however, could well be read as giving hints that some important persons of the freedom struggle in fact also worked for their personal empowerment (see the various allegations in Major Brown's reports in OIOC, $\mathrm{L} / \mathrm{P} \& \mathrm{~S} / 13 / 1860)$.

\section{Power/Knowledge in the Northern Areas of Pakistan}

The intimate, double-edged relationship between British colonial power and knowledge in South Asia is well documented and was in operation also in the Gilgit Agency. The British mode of domination there, producing a certain consensus of power, relied heavily on knowledge and surveillance of local conditions. ${ }^{23}$ The British strategy of recruiting locals as instruments of power and distributing rank and honor

\footnotetext{
${ }^{21}$ This truth extends also to some of the veterans of the freedom struggle. The hero of freedom, Babar Khan, was at the time of the revolution of Gilgit in 1971 superintendent of police in the town - that is, an important part of the Pakistani administration. Accordingly, the freedom was also marked by the insurgency of the people against those who had purportedly brought them freedom.

${ }^{22}$ In 1994-95, the former barracks of the Gilgit Scouts in the center of Gilgit Town were demolished and replaced by a market. Only the "oath hall" has been preserved, the small building where in 1947 the officers took their oath for the freedom struggle. A plate outside commemorates this event. By now the scouts have been reduced to a museum item.

${ }^{23}$ Sometimes, however, British strategies of gathering knowledge in the British agency were not successful, but rather furthered the production of uncontrollable rumors (Sökefeld 2002).
} 
to preempt the opposition of those who might suspect that their own power was to be annexed and simply replaced by the British required knowing who, according to local structures and concepts, could be entitled to certain positions. The strategy required knowing and reconstructing local categories of people so that the right people were won over by the British. Not everybody in Gilgit was eligible for service in the Gilgit Scouts. In fact, a considerable part of the population was outright excluded from accessing that new source of symbolic and material capital. All men belonging to qōm ${ }^{24}$ regarded locally as "low" and "foreign" (both categories converge to a great extent) — that is, all those not categorized as khāndān $\bar{\imath}$ (of a family) (see Sökefeld 1997b, 97-102; 1998b, 151-56) — could not become scouts. For instance, the Kamin, Dom, Pashtun, and the different groups of Kashmiri were excluded from recruitment. ${ }^{25}$ The scouts of the Gilgit company belonged almost exclusively to the qōm Yeshkun, Ṣinn, and Rōnō and to the raja family. The British recorded qōm membership in census reports and settlement records. In Gilgit too, then, British rule was directed into an "idiom of order" (Guha 1997, 24-25), but this order was not exclusively conceived of as British order but also as local order, which to be maintained required a fair amount of local knowledge.

Comparable to the British construction of caste in India, the British practice of categorizing and fixing categories by writing had an important influence on these categories in Gilgit. Today, people sometimes argue that they belong to a certain qōm because it has been written that they do so (Sökefeld 1994). Very often the British practice of recruiting only members of particular qōm is quoted today as proof that these qōm were/are indeed of a higher quality than the others. The colonial way of categorizing thus became integrated into the discourse of "natives." And here, again, the British compare favorably with the Pakistani: the Pakistani administration did not recognize and employ these categories ${ }^{26}$ - that is, Pakistan did not sustain the "local" order by recognizing important differences, therefore producing disorder. One almost unanimously resented fact understood locally as an effect of this disorder is that more and more "people from outside" found their way into the area. ${ }^{27}$

The relationship here of power and knowledge enters the next stage. The nationalist discourse produces a new kind of knowledge that endeavors to reconstruct order, explain the difference between the Northern Areas and Pakistan, and constitute people of the Northern Areas as a nation based on common history, culture, language, and territory (Sökefeld 1999). This knowledge of the nation is essentializing: it disregards important differences within what is supposed to be the nation and portrays it as a timeless essence that existed before colonial intervention and domination in the region began and that in its core could not be affected by this intervention. Take, as an example, the following passage from a political pamphlet:

${ }^{24}$ The term $q \bar{o} m$ has a wide range of meanings, from "kinship-oriented group" to "political nation" (Sökefeld 1998a). The groups called "tribes" and "castes" in British sources are locally called qōm.

${ }^{25}$ One could easily imagine that the Gilgit Scouts Corps would have had a very different effect on the stabilization of British power in the Gilgit Agency if the British had recruited mainly these wrong people.

${ }^{26}$ When the freedom forces had to be enlarged quickly in 1947-48 because of the Kashmir War, men of other qōm were recruited for the first time. Only the very first post-1947 census of Gilgit still recorded these qōm memberships (Government of Azad Kashmir 1951, pt. 2, sec. B, table 2).

${ }^{27}$ This opinion can frequently be heard in the discourse of those who claim to be the "real" people of Gilgit (Sökefeld 1997b, 1998b). 
For centuries, the Northern Areas [Gilgit Baltistan] had constituted a single unity in historical, geographical, and political respect. Since the beginning of its history, this region has been one; whenever sometimes some foreign attacker occupied some [part of the] region, then the other regions too came under that rule. This is the reason why the people of these areas have fought together against foreign aggressors. ... In this manner, the local rulers with their nationalist zeal have preserved the historical, geographical, political, and cultural identity of the country. ${ }^{28}$

("Manshūr" n.d., 3-4)

In the nationalist discourse, knowledge becomes subversive, directed against the dominant power, challenging the legitimacy of its authority. This subversive essentialism poses a danger to Pakistani control, especially when it is enacted publicly. Thus, the public expression of the oppositional view on the fiftieth anniversary of Pakistan's independence in August 1997 was strictly prevented by Pakistani force.

Those writing about the Northern Areas, producing and disseminating knowledge about the region and its people, are entangled in power relations too. This is obvious in the case of the British colonial authors who could write about the area and its culture, history, and languages because British control had been extended into the region. Three of the British authors writing about the Gilgit Agency were political agents (Biddulph, Durand, and D. L. R. Lorimer) and were themselves representatives of power. The departure of the British did not sever the entanglement of power and knowledge. The access to knowledge is still guarded and restricted by power.

The independence of Pakistan has curbed the power of foreigners wishing to enter the Northern Areas for the purpose of research. They need a permit from the authorities. Shortly after I had arrived in Gilgit in summer 1991 for fieldwork, a young man asked me why and how I had come and whom I had to ask to be allowed to do research in the town. When I responded that I had to get an official permit from the Government of Pakistan, he said: "But you do not research about them, so you should have asked us!" I was made aware that the relation between power and knowledge had not yet been decolonized in the Northern Areas. Still, I had to ask some distant, foreign, and powerful agency that controlled access to that knowledge, not the people about whom I was to gather information. What I could learn and write about the Northern Areas was inevitably part of a "game" (or maybe more correctly, "struggle") of power. Once I had acquired access by way of having been granted a research permit, I was also approached by oppositional political activists who wanted to impart to me their perspective of matters. Tulio Maranhao reminds us that "informants" of research never just inform the researcher but also try to convince him or her of something (1985, 298). This is even more the case when one is researching politics of identity. Thus, activists tried to convince me that the people of the Northern Areas constituted a nation different from that of Pakistan and that this nation was colonized and oppressed by Pakistan. Although I was certainly sympathetic to the activists' demands for political rights, I felt uneasy because they framed this struggle in nationalist terms. As a German and because of Germany's special historical experience with nationalism, I am quite critical of any kind of nationalism, although I understand, rather reluctantly, that it can be an instrument to a certain degree of liberation from foreign rule.

Besides the views in foreigners' and nationalists' writings, there is also what could be regarded as the "official view" of the matter. Pakistani historian Ahmad Hasan Dani writes in his History of Northern Areas of Pakistan about the freedom struggle:

${ }^{28}$ In this passage, Pakistani rule in Gilgit is not mentioned, but later the pamphlet states that Pakistan has bound the people of the Northern Areas in "inhuman colonial slavery" ("Manshūr" n.d., 5). 
It is the spirit of Jehad that inspired the people of Gilgit and Baltistan and they enrolled themselves as volunteers to fight along with their men of Gilgit Scouts. The blood of the martyrs who died in the battlefield, the material and moral support that the entire people of this Zone gave for [the] fight for freedom and their voluntary offer to integrate their land with Pakistan, prove the will of the people to cut themselves away from the Maharaja and throw away his decision to join with India. Under this circumstance Northern Areas of Pakistan came into existence to join freely out of its own accord with Pakistan.

(1989, 401)

This history, written at the request of $\mathrm{Zia}$ ul Haq and sponsored by the National Institute of Historical and Cultural Research (Dani, oral communication, October 1992), celebrates the freedom struggle but gives no hint that the goal of the freedom fighters - the integration into Pakistan — was never achieved. It is precisely such historical accounts that the nationalist writings attempt to subvert.

How does one write a history of colonialism and postcolonial colonialism in such a contested field? I definitely do not share the essentialized vision of the Northern Areas as it is constructed in nationalist discourse. On the other hand, the essentialized nation cannot altogether be denied because the people of the Northern Areas as a whole are marked by the essentializing effects of Pakistani domination: they all, irrespective of any internal difference, are denied participation in the formation of Pakistan's constitutional institutions, including their own administration. This condition, then, impresses a certain degree of polarization upon a historical account even if it acknowledges that there is no political perspective shared by all and struggles to remain aware of the range of relations that crosscut these polarities: relations of collaboration, of employing foreign power for local purposes, of material gain based on the colonial political conditions, and so on. A politically conscious history, in my mind, should not endeavor and cannot achieve a postmodern(ist) deconstruction of all essentialism, turning all polarities into ambivalence or all difference into hybridity. Under the universalist, maybe old-fashioned and outdated (but outdated only in the "theoretically correct" [Frankenberg and Mani 1993,301] academia of the metropolis, not in the Northern Areas) premise that all humans should enjoy a degree of equality in political participation, polarizing historical accounts of the Northern Areas need to be written as long as polarizing effects of power are at play.

The production of knowledge by writing, accordingly, not only is subjected to power but also aspires for power or, more modestly, for a change in power relations. The subalternity that is made known by being written about accuses by nature the dominant force. Those subalterns who write or speak and reframe/reconstruct their subalternity in their own terms constitute a danger to the dominant by simply challenging the dominant group's representations. "The moment the subaltern has stepped into the arena of representation and negotiation, this is the first mark of a movement away from his or her former position. The ability to 'speak up' to the hegemonic forces is a step towards becoming an organic intellectual. However, to become such a representative is already a movement from the condition that is represented. The subaltern condition cannot even bear the privilege of its own 'organic intellectuals"' (Papastergiadis 1997, 276). ${ }^{29}$ Producing a nationalist discourse of the Northern Areas gives a totally new significance to continuing political structures. Therefore, this discourse, though it is authored only by a minority of the Northern Areas' population,

${ }^{29}$ The "real" subalterns, then, cannot write or speak; they are the "other" of discourse, remaining outside representation (Spivak 1993). 
is regarded with high suspicion and is met with determined repression, if deemed necessary. The discourse establishes a new power, the nation. Its essentialism is a tool of empowerment because it enables the recruitment of "the people of the Northern Areas" into that nation irrespective of whether a person conceives of himself or herself in these terms. Essentialism here overrides the minority status of a minority discourse and constructs a new majority. ${ }^{30}$ Essentialism becomes a matter of strategy (Spivak 1988): it is an instrument in the politics of representation.

\section{Conclusion}

In this article, I have discussed aspects of the history of what is today called the Northern Areas of Pakistan. Starting with the beginning of Kashmiri and British domination, I have shown how the British shifted their discourse of legitimacy to distinguish their own mode of domination from that of the Kashmiri. Employing instruments of domination such as the Gilgit Scouts to co-opt local agency, the British, in contrast with the Kashmiri, were indeed able to develop a partial hegemony. Although British domination was never really challenged, hegemony was not complete and did not prevent the expression of discontent and moments of resistance. When the British retreated from the area, the Kashmiri were unable to assume the position of the British and develop a position of power in Gilgit. The insurrection against the Kashmiri administration called for accession to Pakistan, but the Northern Areas remained in the marginal state of a disputed territory. Pakistani rule was in the beginning characterized by both a high degree of consensus and the continuation of colonial structures and practices. During the first decades of "independence," these practices were only slowly identified by the local population and given the signification of colonial practices. Opposition to Pakistani domination grew and culminated in recent years in a nationalist movement demanding independence from Pakistan.

We may distinguish different modes of domination in the history of the Northern Areas, according to the degree to which violence was employed and consensus was achieved. A mode of domination depends not only on the strategies executed by those who dominate but also, in accordance with the Foucauldian concept of power, on the perception of these strategies by the subaltern population. Thus, colonial domination is a matter of both certain structures and practices of domination as well as the signification attributed to these structures and practices. In this respect, Kashmiri domination was very different from the British colonial system. Later, after 1947, Pakistan's rule in the Northern Areas shifted clearly from a rule of freedom to a new colonialism in local discourse and perception. The relationship of structure and signification in modes of domination reflects certain conditions of power and knowledge. British knowledge of local circumstances in particular enabled them to develop strat-

\footnotetext{
${ }^{30}$ This discursive construction of a majority also creates new minorities, namely, those that are excluded by the nationalist vision or who exclude themselves. In Gilgit there is a group of people who are called Kashmiri and regarded as a "lower" qōm. There are significantly fewer adherents to the new nationalism among these Kashmiri than there are among other qōm. This may be because the Pakistani administration ended the discrimination against the Kashmiri groups-for example, by recruiting them into the Azad Forces. On "Pakistan Day" (August 14), there has been in the last few years much richer and more festive decoration in the Kashmiri parts of Gilgit's bazaar than in bazaar areas dominated by other groups. I owe this information to Katrin Gratz.
} 
egies of power that resulted in partial hegemony and allowed them to reduce the execution of force to a minimum. The emerging picture, then, is quite complex and does not allow in every case for an easy and clear-cut distinction between those who wielded power and those who were subjected to that power. The effectiveness of the British system seemed to be based precisely on the British endeavor to blur a definite distinction to a certain extent and to prevent the emergence of a consciousness of a clear contrast and opposition between British colonizers and the local colonized. This is very different from the recent political situation in Gilgit: the nationalist movement produces a kind of knowledge that emphasizes the difference between locals and the Pakistani administration, thereby promoting the recognition of that administration as a colonial system.

Taken literally, the title of my article is a paradox. This contradiction is the central subject of postcolonial studies: colonialism did not simply end with independence. The contradiction echoes the difficulties of the term "postcolonial." Pakistan is of course a postcolonial state, but this postcoloniality acquires very different meanings depending on different perspectives within the country. This difference emerges not only in the political discourse of the Northern Areas but also in those of other movements alleging the discrimination of peripheral regions by the powerful center. That a state is "postcolonial" in a certain set of political relations does not preclude its colonial character in another set. The contradiction then describes appropriately the political circumstances found today in the Northern Areas of Pakistan. Some kind of colonialism has ended, but some other kind, originating from the end of the first, is still working, engendering an anticolonial struggle, similar to that against British rule in that it too is framed in nationalist terms - only that the meaning of "nation" has changed and the anticolonial struggle before 1947 did not take place in the Gilgit Agency. The paradox of postcolonial colonialism, then, strongly reminds us of the fact that the meaning of history is not a matter of either/or logics, but of ambivalence and multivocality inscribed onto a range of conflicting subject positions and a struggle over signification.

\section{List of References}

Abdul Hamid Khan. 2001. The Last Colony of 21st Century: Balawaristan. Gilgit: Balawaristan National Front.

Alder, G. J. 1963. British India's Northern Frontier, 1865-95: A Study in Imperial Policy. London: Longmans.

Amar Singh Chohan. 1984. The Gilgit Agency, 1877-1935. New Delhi: Atlantic Publishers and Distributors.

Amir Hamza. n.d. "Parawise Comments by Amir Hamza Senior Superintendent of Police on Reply of the Attorney General of Pakistan Submitted in the Supreme Court Regarding Constitutional Status of Gilgit Pakistan.” Mimeograph.

Arendt, Hannah. 1970. On Violence. New York: Harcourt, Brace, Jovanovich.

- 1986. "Communicative Power." In Power, ed. Steven Lukes. Oxford: Basil Blackwell.

Babar Khan. 1973. "Chauda javānōnnē Gilgit mēn Ḍōgrōn kē iqtedār kā khātima kar dīa" [Fourteen Soldiers in Gilgit Ended the Power of the Dogras]. Bebak January 20-February 10:23-28, 82-83.

Balawaristan National Front. n.d. "A Wake-Up Call to a Nation in Chains of Slavery." Pamphlet.

Bнавна, Номі K. 1994. The Location of Culture. London: Routledge. 
Biddulph, John. 1880/1971. Tribes of the Hindoo Koosh. Graz: Akademische Druckund Verlagsanstalt.

Chakrabarty, Dipesh. 2000. Provincializing Europe: Postcolonial Thought and Historical Difference. Princeton, N.J.: Princeton University Press.

Dani, Ahmad Hasan. 1989. History of Northern Areas of Pakistan. Islamabad: National Institute of Historical and Cultural Research.

Drew, Frederic. 1875/1980. The Jummoo and Kashmir Territories. Karachi: Indus Publications.

Durand, Algernon. 1899/1977. The Making of a Frontier: Five Years' Experience and Adventures in Gilgit, Hunza, Nagar, Chitral, and the Eastern Hindu-Kush. Karachi: Indus Publications.

Foucault, Michel. 1979a. Discipline and Punish. Trans. Alan Sheridan. London: Allen Lane.

- 1979b. "Powers and Strategies: An Interview with Michel Foucault by the Révoltes Logiques Collective." In Michel Foucault: Power, Truth, Strategy, ed. Meghan Morris and Paul Patton. Sydney: Feral Publications.

- 1980. "The Confession of the Flesh." In Power/Knowledge: Selected Interviews and Other Writings, 1972-1977, trans. and ed. Colin Gordon. New York: Pantheon Books.

- 1982. "The Subject and Power." In Michel Foucault: Beyond Structuralism and Hermeneutics, ed. Hubert Dreyfus and Paul Rabinow. Brighton: Harvester Press.

Frankenberg, Ruth, and Lata Mani. 1993. "Crosscurrents, Crosstalk: Race, 'Postcoloniality,' and the Politics of Location." Cultural Studies 7:292-310.

Ghansar Singh. 1983. "Gilgit Before 1947." Booklet.

Goffman, Erving. 1959. The Presentation of Self in Everyday Life. New York: Doubleday.

Government of Azad Kashmir. 1951. Azad Kashmir, Gilgit, and Baltistan. Pt. 2 of Census of Azad Kashmir, 1951. N.p.

Gramsci, Antonio. 1971. Selections from the Prison Notebooks, trans. and ed. Quintin Hoare and Geoffrey Nowell-Smith. New York: International Publishers.

Guha, Ranajit. 1982. "Some Aspects of the Historiography of Colonial India." In vol. 1 of Subaltern Studies. Delhi: Oxford University Press.

- 1997. Dominance without Hegemony: History and Power in Colonial India. Cambridge, Mass.: Harvard University Press.

Hall, Stuart. 1996. "When Was 'the Postcolonial'? Thinking at the Limit." In The Postcolonial Question: Common Skies—Divided Horizons, ed. Iain Chambers and Lidia Curti. London: Routledge.

Hasan, Mushirul, ed. 1993. India's Partition: Process, Strategy, and Mobilization. Delhi: Oxford University Press.

Hindess, BARRY. 1996. Discourses of Power: From Hobbes to Foucault. Oxford: Blackwell.

Jalal, A yesha. 1985. The Sole Spokesman: Jinnah, the Muslim League, and the Demand for Pakistan. Cambridge: Cambridge University Press.

KNight, E. F. 1893/1991. Where Three Empires Meet: A Narrative of Recent Travel in Kashmir, Western Tibet, Gilgit, and the Adjoining Countries. Lahore: Sang-e-Meel Publications.

Kreutzmann, Hermann. 1996. Ethnizität im Entwicklungsprozeß: Die Wakbi in Hochasien [Ethnicity in Development: The Wakhi in High Asia]. Berlin: D. Reimer.

"Manshūr" [Communication]. n.d. Mimeograph. 
Maranhao, Tulio. 1985. "The Hermeneutics of Participant Observation." Dialectical Anthropology 10:291-309.

McClintock, Anne. 1992. "The Angel of Progress: Pitfalls of the Term 'Postcolonialism."” Social Text 31-32:84-98.

Müller-Stellrecht, Irmtraud. 1981. "Menschenhandel und Machtpolitik im westlichen Himalaja" [Slave Trade and Politics of Power in the Western Himalaya]. Zentralasiatische Studien 15:391-472.

Oriental and India Office Collection (OIOC). Political and Secret (P\&S) Papers. Kashmir Residency (R/2) Papers. British Library, London.

Papastergiadis, Nikos. 1997. "Tracing Hybridity in Theory." In Debating Cultural Hybridity: Multi-Cultural Identities and the Politics of Anti-Racism, ed. Pnina Werbner and Tariq Modood. London: Zed Books.

Prakash, Gyan. 1992. “Can the 'Subaltern' Ride? A Reply to O'Hanlon and Washbrook." Comparative Studies in Society and History 34:168-84.

Qudratullah Beg. 1967. "Tārīkh tamīr sanțral Jamā‘ at Khāna Gilgit” [History of the Construction of the Central Jamā' at Khana Gilgit]. Booklet.

SAID, EDW ARD W. 1994. Culture and Imperialism. London: Vintage.

-1995. Orientalism: Western Conceptions of the Orient. London: Routledge and Kegan Paul, 1978. Reprint, Harmondsworth: Penguin Books.

Scott, James C. 1990. Dominance and the Arts of Resistance: Hidden Transcripts. New Haven, Conn.: Yale University Press.

Shah Rais Khan. 1987. Tarikh-e Gilgit [History of Gilgit]. Ed. A. H. Dani. Islamabad: Center for the Study of the Civilizations of Central Asia.

Sökefeld, Martin. 1994. "Ṣin und Yeśkun in Gilgit: Die Abgrenzung zwischen zwei Identitätsgruppen und das Problem ethnographischen Schreibens" [Șīn and Yeśkun in Gilgit: The Boundary between Two Identity Groups and the Problem of Ethnographic Writing]. Petermanns Geographische Mitteilungen, no. 138:357-69.

- 1997a. "Jang āzād $\bar{\imath}$ : Perspectives on a Major Theme in Northern Areas' History." In The Past in the Present: Horizons of Remembering in the Pakistan Himalaya, ed. Irmtraud Stellrecht. Cologne: Köppe.

- 1997b. Ein Labyrinth von Identitäten in Nordpakistan: Zwischen Landbesitz, Religion und Kaschmir-Konflikt [A Labyrinth of Identities in North Pakistan: Between Land, Religion, and the Kashmir Dispute]. Cologne: Köppe.

- 1998a. "On the Concept 'Ethnic Group."” In vol. 2 of Karakorum-HindukushHimalaya: Dynamics of Change, ed. Irmtraud Stellrecht. Cologne: Köppe.

—. 1998b. "'The People Who Really Belong to Gilgit': Theoretical and Ethnographic Perspectives on Identity and Conflict." In Transformations of Social and Economic Relationships in Northern Pakistan, ed. Irmtraud Stellrecht and HansGeorg Bohle. Cologne: Köppe.

_. 1999. "Bālāwaristān and Other Imaginations: A Nationalist Discourse in the Northern Areas of Pakistan." In Ladakh: Culture, History, and Development between Himalaya and Karakorum, ed. Martijn van Beek, Kristoffer Brix Bertelsen, and Poul Pedersen. Aarhus: Aarhus University Press.

- 2002. "Rumours on the Northern Frontier: The British, Pakhtun Wali, and Yaghestan." Modern Asian Studies 36:299-340.

Spivak, Gayatri Chakravorty. 1988. "Subaltern Studies: Deconstructing Historiography." In Selected Subaltern Studies, ed. Ranajit Guha and Gayatri Chakravorty Spivak. New York: Oxford University Press.

- 1993. "Can the Subaltern Speak?" In Colonial Discourse and Post-colonial Theory: A Reader, ed. Patrick Williams and Laura Chrisman. New York: Columbia University Press. 
Stellrecht, Irmtraud. 1998. "Trade and Politics—The High-Mountain Region of Pakistan in the 19th and 20th Century." In Transformations of Social and Economic Relationships in Northern Pakistan, ed. Irmtraud Stellrecht and Hans-Georg Bohle. Cologne: Köppe.

Syed DurRani. 1985. "Inqilāb-e Gilgit-ēk mukhtasar jāiza" [The Revolution of Gilgit—a Brief Review]. In Qarāqarum Hindükush, ed. Manzum Ali. Gilgit: n.p.

Talbot, Ian. 1996. Freedom's Cry: The Popular Dimension in the Pakistan Movement and Partition Experience in North-West India. Karachi: Oxford University Press.

Thakur Singh. 1917. Assessment Report of the Gilgit Tabsil. Lahore: Khosla Brothers.

Touraine, Alain. 1981. The Voice and the Eye: An Analysis of Social Movements. Trans. Alan Duff. Cambridge: Cambridge University Press.

Usman Alı. 1990. Gilgit kē rōg kahān̄̄ [The Painful Story of Gilgit]. Lahore: Maqbūl Academy.

Vans Agnew, P. A. 1847. "Diaries of Mr. P. A. Vans Agnew, Assistant to the Agent, Governor-General, North-West Frontier, on Deputation to Gilgit, 1847." In Punjab Government Records, Lahore Political Diaries, 1847-1849. Lahore: Punjab Government Publications.

Westwood, Sally. 2002. Power and the Social. London: Routledge.

Yasin, Madhavi. 1984. British Paramountcy in Kashmir, 1876-1894. New Delhi: Atlantic Publishers and Distributors. 
